\title{
5. Fiscal Decentralization in the Middle East and North Africa: Deciphering Motives and Outcomes ${ }^{1}$
}

\author{
Erik Vollmann and Miriam Bohn
}

The delegation of state tasks and responsibilities from the central government level to regional and local levels, also known as decentralization, is a ubiquitous phenomenon. Elected subnational governments seem omnipresent in democracies. OECD governments spend a significant portion (40.4\% in 2016) of their government expenditure at the subnational levels (OECD and UCLG 2019). Because decentralization is associated with good governance, development, and democracy, the international community promotes and supports decentralization reforms in the Middle East and North Africa (for an overview of the arguments see Demmelhuber et al. 2020; Harb and Atallah 2015b; see also chapter 2). MENA states are among the most centralized in the world. But even these regimes have opted for some form of subnational government and most of them include elected subnational councils (see Figure 1).

1 We are indebted to Ibrahim Bebars, Jennifer Hecht, Katharina Nicolai, and Julia Zimmermann for their invaluable research assistance. 
Figure 1: Local governments elected

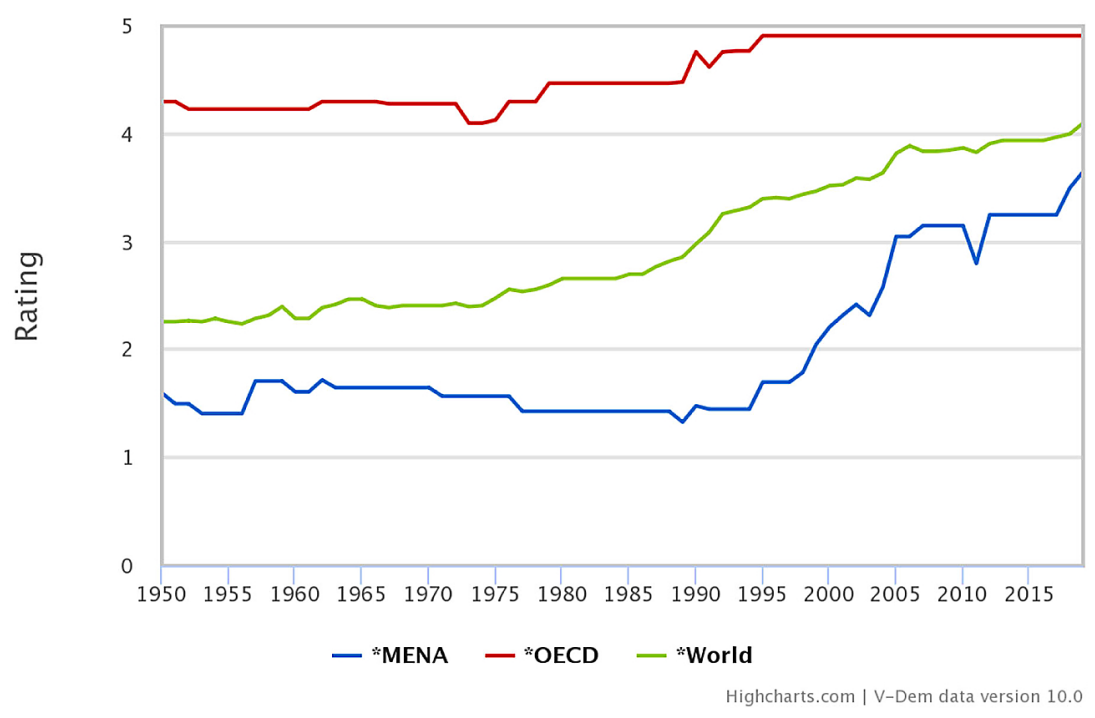

V-Dem (2021), coding: 0: Generally, offices at the local level are not elected. 1: Generally, the local executive is elected but not the assembly. 2: Generally, the local assembly is elected but not the executive. 3: Generally, the local executive is elected and there is no assembly. 4: Generally, the local assembly is elected and there is no executive. 5: Generally, the local executive and assembly are elected.

Despite an upward trend in recent years, particularly during the last decade, the effective power and autonomy of elected subnational governments in the MENA is more limited than in other world regions. The local and peripheral origins of the 2010/2011 uprisings were clear expressions of societal discontent with central power and regional socioeconomic imbalances. Hence, the protests brought back to life the discourse on decentralization in many MENA countries. Decentralization laws followed, most prominently in Morocco (new constitution, major decentralization laws in 2015, with regional and local elections in 2015); Jordan (new decentralization law in 2015, with local and regional elections in 2017); and Tunisia (new constitution, extensive decentralization laws and local elections in 2018). All of these reform projects focus on the establishment or advancement of local and regional subnational governments (though the regional councils in Tunisia have not yet been elected) (Vollmann 2020). Significantly, these decentralization processes have one factor in common: They are regime-controlled, top-down initiatives. The reforms are pushed by the monarchies in Morocco and Jordan, while the Tunisian decision to in- 
clude decentralization in its new constitution originated from a transitional and pro-democratic impulse in a countermove to the heavy centralism of the old regime (Kherigi 2017). Despite a strong centralist state order in Egypt, nominal decentralization was long necessary to implement state policies in order to reduce social and regional disparities (Demmelhuber and Roll 2009). Today, decentralization is stifled by the ultra-centralism of as-Sisi's regime that took over power later in 2013.

We argue that the present decentralization processes in the MENA post 2011 are central state reactions to protests against long-standing local government malfunction and economic deprivation of the peripheries. The decentralization discourses and reforms in all four cases use a language of "positive discrimination" and promise a reformed relationship of the center and the periphery. In theory, this should lead to an improvement of subnational administrative efficiency and an empowerment of the long-neglected periphery.

Under the conditions of ambiguous legal outlines with vague or contradictory wording and long-standing centripetal patron-client relationships, the outcome of decentralization reforms is not always the participative, democracy-enhancing and reconciliating model that governments and international donors advertise. To provide subnational institutions with sufficient and independent funds so that they can freely execute their tasks and rights is a necessary precondition of meaningful decentralization. The fiscal dimension is one of the focal points for the political economic analysis of decentralization effects alongside the clear-cut separation of competences. Fiscal decentralization sheds light on the will of political rulers to commit to decentralization and on the deficits of current local governance arrangements in the region.

We chose Morocco, Jordan, and Tunisia as the three MENA regimes with the most ambitious decentralization reforms after the Arab uprisings, as well as Egypt, whose decentralization process is suppressed by as-Sisi's autocratic rule as a contrasting case for our analysis. Since 2011, decentralization has led to an expansion of subnational governments' power in Jordan, Tunisia, and Morocco, but not in Egypt (see Figure 2). Are these developments reflected in the degree of fiscal decentralization? 
Figure 2: Strength of local governments in comparison

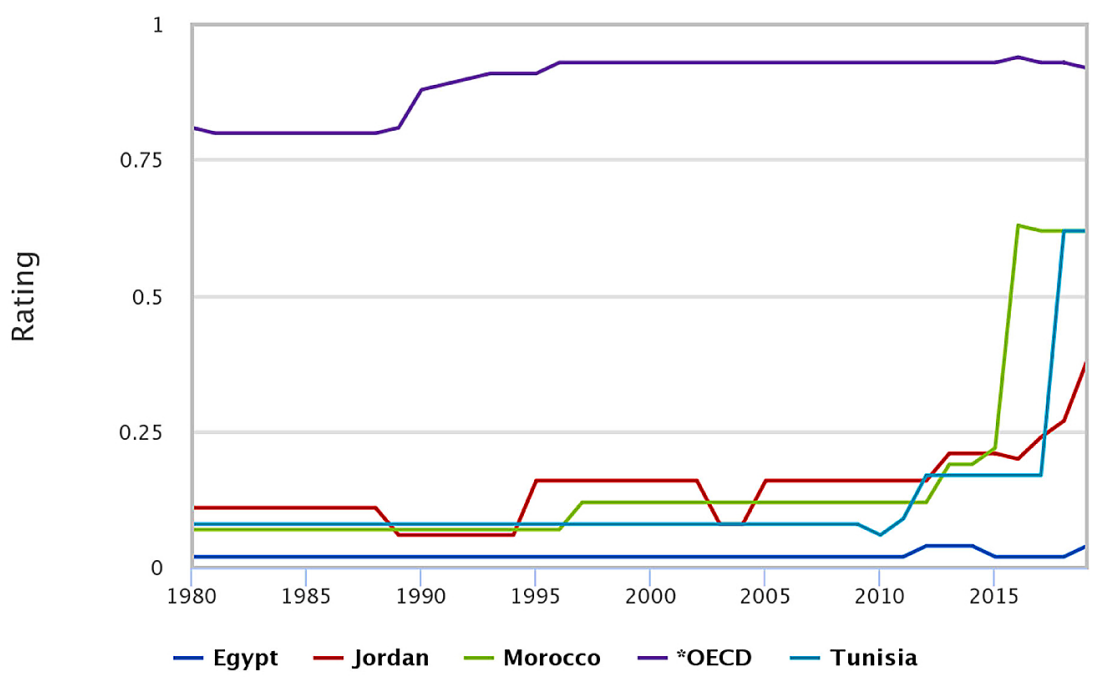

Highcharts.com I V-Dem data version 10.0

V-Dem (2021), combination of elected local governments and their relative strength vis-à-vis unelected bodies on the same level; high values indicate high power of elected local governments.

Building on this volume's theoretical framework (see chapter 2), we assess the degree of the regime's commitment and meaningful implementation of decentralization measures in all four countries. We analyze the evolution of fiscal decentralization and thereby focus on the role of regional disparities as well as on the connection between fiscal decentralization and neopatrimonialism. Decentralization projects are no one-size-fits-all approach. We argue that the strong neopatrimonial character of politics in our region of analysis changes the trajectory of decentralization reforms. We combine an in-case comparison with a between-case comparison to identify common trajectories and country-specific outputs. Reliable data on public finance, let alone subnational finance, are very scarce in the MENA region. Most quantitative studies on (fiscal) decentralization thus exclude the Arab world from their analyses. With a combination of quantitative data on fiscal decentralization and local finance, and qualitative material from original fieldwork research and secondary literature, we aim to 
narrow this gap by shedding light on the dynamics of fiscal decentralization in the MENA. ${ }^{2}$

\section{Fiscal decentralization, effective local governance and neopatrimonialism in the} MENA

Proper funding is necessary for subnational governance reforms. A basic assumption of effective decentralization is that a transfer of powers and responsibilities to subnational institutions must be accompanied by a transfer of proper funding (Vollmann 2020; Bergh 2021). Transformation literature, as well as the proponents of decentralization policies, claim that the reforms aim at boosting economic development when the fiscal relationship between the center and its territories is improved (Demmelhuber et al. 2020).

We argue that most large-n-studies neglect the case-sensitive processes of decentralization reforms, though we agree with the literature that the level of fiscal decentralization is of utmost importance to assess the potential and success of state-led subnational governance reforms in the MENA region. Underfunding and insufficient competencies to raise own revenues decreases the potential for subnational governments to work independently or even effectively.

The ideal degree of fiscal decentralization is of course dependent on the actual form of decentralization (World Bank 2001) ${ }^{3}$ : Purely administrative forms of decentralization (e.g., regional ministerial branches) may function with limited expenditure autonomy. They can cope with strict guidelines from the center on how to spend their budget. Subnational autonomy

2 Our analysis draws on original fieldwork in Morocco (April 2018 - May 2018 and October 2018 - December 2018), Jordan (April 2018 - May 2018, October 2018 November 2018 and January 2020 - February 2020), and Tunisia (October 2019 November 2019 and January 2020 - February 2020) where we conducted semistructured interviews $(n=162)$ with politicians and state employees, civil society actors, researchers, journalists, and foreign observer organizations on the central, regional, and local government levels. One thematic section of our interviews focused on financial organization and assessments of the state and shortcomings of central-subnational fiscal relations. We also need to stress the problems of fiscal data availability and quality in the MENA region, whose statistical capacity lags behind other world regions. For an extensive discussion of both matters, see chapter 3.

3 For a more extensive discussion of different forms and models of decentralization, see also chapter 2 . 
over revenues or the power to generate own income, e.g. by subnational taxes or fees, is also not strictly necessary for some types of administrative decentralization. Since government agencies or subnational ministerial branches are part of the executive, their funding is often directly controlled by the central state. Forms of political decentralization, i.e. (quasi-)autonomous bodies or elected institutions often imply higher degrees of expenditure and revenue autonomy. The actual structure of intra-state fiscal relations is, however, extremely intricate and dependent on a plethora of political rationales.

Throughout the MENA region, governments have imparted elected councils with budgetary power and most of them are theoretically empowered to collect fees for subnational service provision or even local taxes (Harb and Atallah 2015a; Kherigi 2017). However, the extractive capacity of decentralized institutions in the Arab world is extremely low and the dependency on centralized allocation of funds remains high (Vollmann 2020; Harb and Atallah 2015a). Social institutions (e.g., funds for communal projects gathered by traditional village notables, religious leaders or even just neighbors) often fill the void left by weak central public service provision (Lust and Rakner 2018). However, the compliance or non-compliance between reforms' layouts and actual changes of fiscal relations between the central and subnational levels is an important indicator for the political will and the strategies of political regimes. Decentralization is inefficient if local and regional actors lack the financial means and capacities to fulfill their competences as laid down in the legal framework (Altunbaş and Thornton 2012; Demmelhuber et al. 2020; Houdret and Harnisch 2018). Amendments to the regulation of subnational budget allocation and spending, as well as changes to the amount of central transfers to the periphery, may either lead to an extension or a decline of subnational autonomy. The more a central regime engages with fiscal decentralization and withdraws from subnational financial affairs, the larger the political will to decentralize. The implementation of such changes may appease domestic and international stakeholders and organizations (Vollmann et al. 2020).

Fiscal control is an important factor in a central regimes' monitoring and controlling of their territories. Therefore, an in-depth analysis of fiscal decentralization helps to identify cases of partial decentralization and the manipulation of reforms hijacked to stabilize the regime in authoritarian contexts as a form of authoritarian upgrading (Vollmann et al. 2020; Bergh 2021; Harb and Atallah 2015a; Aalen and Murias 2018). Even if subnational institutions are formally declared to be financially independent bodies, they may de facto have no real fiscal autonomy. The authority over budget 
distribution and spending may remain with central institutions despite the reforms, because it is in the interest of an authoritarian regime to keep subnational institutions financially dependent as an additional control mechanism.

The most commonly used indicator for fiscal decentralization is the share of subnational government spending of total spending or tax revenues. However, we need to broaden our analysis to also capture elements of dependency or independence of subnational institutions from the central state (for an extensive discussion on measurements of decentralization see Dardanelli et al. 2018; Blöchliger 2013). Since local governance is also closely related to regional disparities, we also need to check for subnational variances of fiscal decentralization. Decentralization reforms often formally answer the calls for redistribution of resource imbalances between the center and neglected peripheries. But strategic redistributions of state resources via subnational governments can also lead to fiscal imbalances or even to a form of "subnational rentierism" that creates dependencies on the central state and incentives to align with (authoritarian) regimes, especially if the share of self-generated resources is low and existing transfers favor of economically smaller territories (Gervasoni 2010, 305, 310).

In our research, we moreover take into consideration the relationship of fiscal decentralization and the neopatrimonial character of politics. In the context of neopatrimonialism, subnational resources might be used to uphold and widen networks of cooptation that rely on the access to and distribution of state resources (Demmelhuber et al. 2020; Hibou 2004).

While financial resources are a vital aspect of subnational capacity, the size, experience and quality of subnational human resources are also important for our argument: High staff costs for subnational governments can hamper their ability to implement non-consumptive projects (Vollmann et al. 2020). The (mis-)use of public staffing for purposes of patronage is an important feature of neopatrimonial politics that we must keep in mind when analyzing subnational spending in the MENA region. On the other hand, insufficient staffing and low-qualified personal can obstruct subnational councils' abilities to efficiently put their funds to use (Shalaby et al. 2020). Based on these insights from the literature, our empirical analysis will focus on the following aspects:

(1) Our analysis evaluates the development of subnational expenditure and revenues to assess whether meaningful change has been implemented after the 2011 uprisings.

(2) We elaborate on the regional distribution of decentralization funds to check for the development of center-periphery disparities. 
(3) Funds available are not always funds used. We point out possible problems and shortcomings of subnational governments in their management and spending of money formally at their disposal. This hints to problems regarding the capacities of subnational councils and administrations, relationships between local actors, and enduring political cultures of deference to the center.

(4) To assess the role of decentralized governments, we need to observe the central state influence and mechanisms of neopatrimonial rule. Monetary dependencies, dominance of central state administration over development programs and subnational actors as well as neopatrimonial staffing policies are important indicators for the degree of autonomy of subnational councils.

\section{Fiscal decentralization in Morocco}

\section{Development of subnational finances: MENA forerunner, international latecomer}

Morocco is a forerunner of top-down controlled decentralization reforms in the MENA region. This includes fiscal decentralization. The kingdom possesses decentralized councils on three subnational levels: 12 regions, 63 provincial (rural) and 12 prefectural (urban) councils (the equivalent of governorates in our other cases), and 1503 municipalities. They are the Ministry of Interior's administrative portfolio as are the appointed and hierarchically organized overseers of decentralization (regions: wali, intermediate and local level: governor, local: caid, pasha). The state appointees' de jure and de facto power is strong, despite the legal changes and formal end of the tutelle through the 2015 reform (see chapter 4). The extensive regionalization reforms that were implemented in the constitution of 2011 and the three organic decentralization laws of 2015 gave new powers and responsibilities to subnational institutions. Morocco is the only case among our four cases where earnest attempts to establish a form of regionalism were made. Our fiscal analysis shows that municipalities still are the backbone of subnational expenditure (and revenue), but the reforms have indeed increased the regions' financial influence after 2016 (see Figure 3). The absolute amount of subnational expenditure surged in 2011, as a result of major uprisings and the new constitution, but remained relatively constant until 2016. Recent data implies a clear upward trend since 2017 mostly attributable to the regional level. 
Figure 3: Subnational council expenditure in Morocco, in billion USD

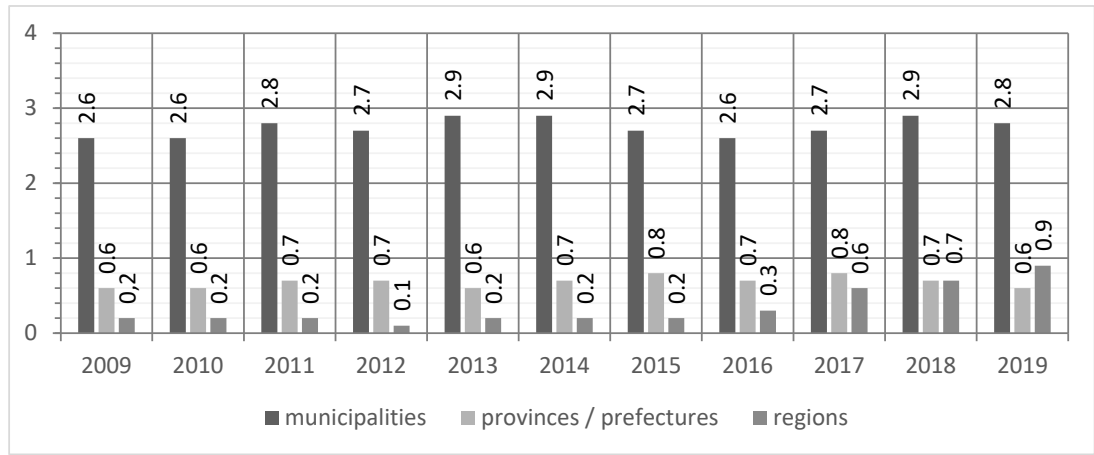

Own calculations based on Moroccan Treasury data.

When contrasted with general public expenditure, the subnational share decreased between the uprisings in 2011 and 2014, because the subnational surge in absolute terms coincided with a general spike in government spending. At least part of this development may be seen as an effort to appease the populace. Measured by the percentage of government spending, Morocco is a big spender at the subnational level in comparison to other MENA countries. However, spending levels remained relatively consistent over the years (see Figure 4). The financial focus of state expenditures has not shifted despite the extensive reforms and the discursive focus on regionalism. Although subnational expenditure as a share of state expenditure clearly increased in the long run (in 2002 it accounted for $8.5 \%$ of government spending), it is still far below OECD spending averages $(40.4 \%$ average, 28.75 average for unitary countries in 2016) (Vollmann 2020; OECD and UCLG 2019). 
Figure 4: Subnational council expenditure in Morocco (percentage of general government spending)

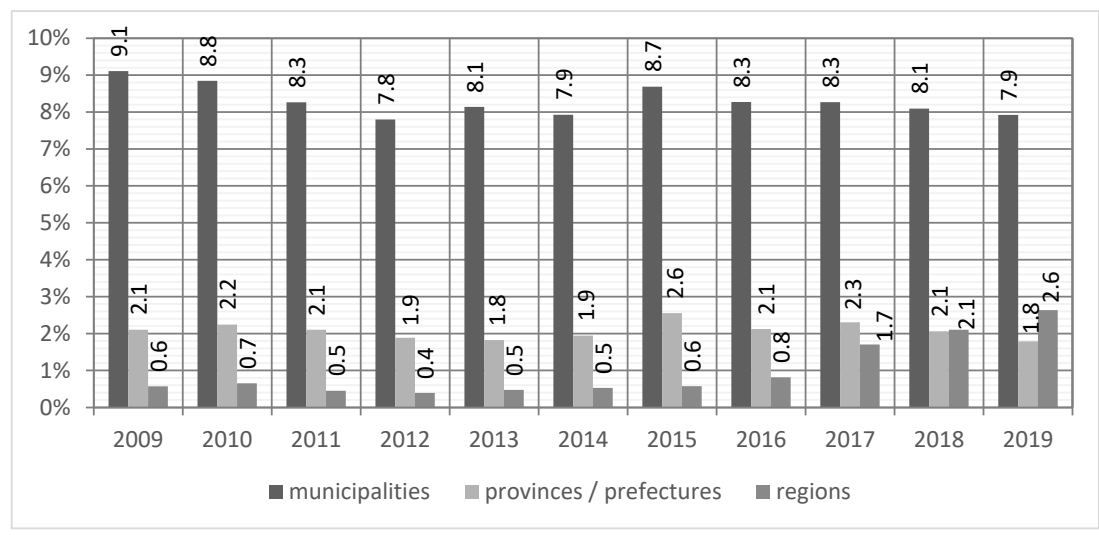

Own calculations based on Moroccan Treasury and IMF data.

Regional disparities: Urban-concentrated spending and advancement of strategic regions

Regional disparities were - as in our other cases - at the heart of the latest decentralization reforms. But rural areas are still disadvantaged in Morocco. The Moroccan state stopped reporting comparative data on rural and urban municipalities after 2015, but the available data from before show a clear dominance of urban spending (and revenues for that matter). Urban municipalities consistently received about $70 \%$ of local expenditures (see Figure 5), even though Morocco is not as urbanized as Jordan or Tunisia. 
Figure 5: Moroccan municipal expenditure (rural and urban in billion USD)

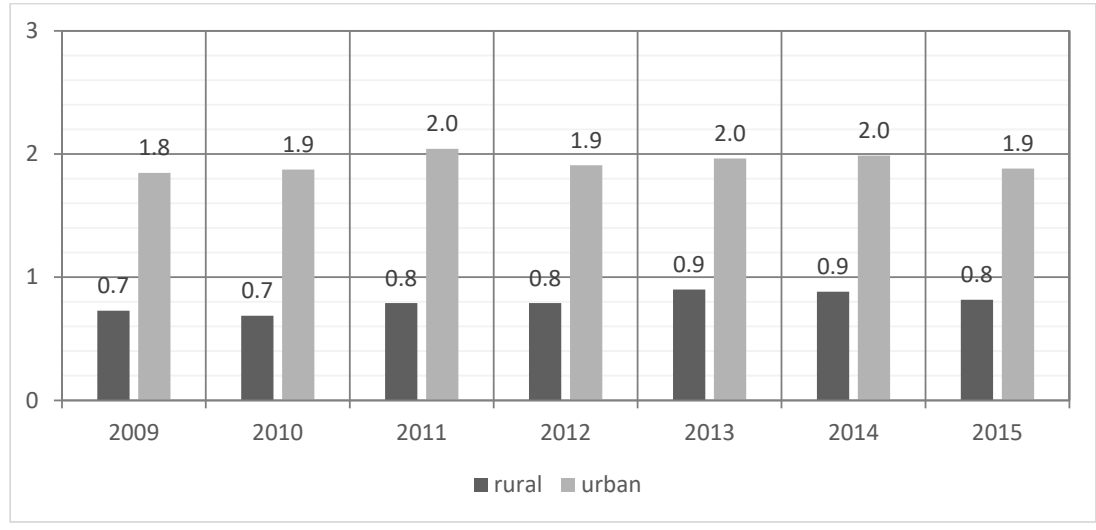

Own calculation based on Moroccan Treasury data.

The data show a clear-cut urban-rural divide, but the central-peripheral division of Moroccan fiscal expenditure is more complex. The central north is responsible for the largest share of subnational expenditures (Casablanca-Settat 18\%, Rabat-Salé-Kénitra 14.1\%, Tanger-Tétouan-Al Hoceima 10\%), but it is also densely populated. Per capita data (see Table 1) show that subnational expenditures clearly favor the (peripheral) regions of the Western Sahara with over 840 USD per capita in Laâyoune-Sakia El Hamra, and around 700 USD per capita in Dakhla-Oued Ed Dahab. Guelmim-Oued Noun (partly in the Western Sahara, about 250 USD per capita) and the Oriental Region (170 USD per capita), which has long been neglected and a driver of social unrest, are also overrepresented. These imbalances show political interest in strategically important peripheral regions, but they are also proof of some efforts to rebalance regional disparities. Since the overall size of subnational expenditures remain modest, this redistribution is however insufficient to rebalance regional development. It does not tip the scales to a degree great enough to overcome the decade-long concentration of prestigious infrastructure projects in Morocco's north. 
Table 1: Regional division of subnational spending in Morocco 2019

\begin{tabular}{|c|c|c|c|}
\hline Region & $\begin{array}{c}\text { Population (2014 } \\
\text { census) }\end{array}$ & $\begin{array}{c}\text { Expenditure 2019 (in } \\
\text { million USD) }\end{array}$ & $\begin{array}{c}\text { Per capita (in } \\
\text { USD) }\end{array}$ \\
\hline Casablanca-Settat & $6,861,739$ & 794.7 & 115.82 \\
\hline Rabat-Salé-Kenitra & $4,580,866$ & 626.4 & 136.74 \\
\hline Marrakesh-Safi & $4,520,569$ & 439.3 & 97.18 \\
\hline Fes-Meknes & $4,236,892$ & 426.9 & 100.75 \\
\hline $\begin{array}{c}\text { Tanger-Tetouan-Al } \\
\text { Hoceima }\end{array}$ & $3,556,729$ & 440.8 & 123.93 \\
\hline $\begin{array}{c}\text { Souss-Massa } \\
\text { Beni Mellal-Khenifra }\end{array}$ & $2,676,847$ & 325.1 & 121.43 \\
\hline Oriental & $2,520,776$ & 297.4 & 117.98 \\
\hline Draa-Tafilalet & $1,635,008$ & 394.4 & 170.42 \\
\hline Guelmim-Oued Noun & 433,757 & 162.0 & 99.09 \\
\hline Laayoune-Sakia El Hamra & 367,758 & 109.5 & 252.43 \\
\hline Eddahkla Oued Eddahab & 142,955 & 311.0 & 845.70 \\
\hline Overall & $33,848,242$ & 99.7 & 697.56 \\
\hline
\end{tabular}

Own calculation based on data of the Moroccan treasury and the Haut-Commissariat au Plan du Maroc.

Subnational finance and the central state: Underfinanced, overcontrolled and bighly dependent on the center

Decentralization in Morocco can only by successful when it has a sound financial base. The fiscal base of the regionalization project has indeed been broadened (also in comparison to the MENA region) but ends still do not meet for subnational councils. An additional element of fiscal decentralization in Morocco is the phenomenon of underspending. Even where funding exists, the implementation of the planned budget is often insufficient. In 2019, 82\% of subnational expenditures on consumption were realized, but only $44 \%$ of planned investments were implemented (TGR 2019). Subnational funds remain underused in the kingdom. There are several reasons for this phenomenon: (1) There exists a conservative spending-mentality of many local leaders, as well as uncertainty regarding the size of central state transfers and the amount of incoming taxes. This contributes to cautious or delayed action (Bergh 2017; Mhammedi 2019). 
(2) Poor management and the employment of untrained councilors, in combination with weak technical infrastructures and legal ambiguities also play a role. (3) Council actions are delayed or inhibited by political infighting. (4) Many council presidents are reluctant to take action without the approval of the central state administration, despite the formal end of the administrative tutelle, i.e. the strong ex-ante oversight of decentralization by the Ministry of Interior. (5) The ex-post oversight that controls the legality of council decisions is time intensive and hampers subnational government action. (Bergh 2020; 2021; Vollmann et al. 2020; Mhammedi 2019) We observe a close connection between the curbed potential of subnational governments' decision-making and central state influence, neopatrimonialism in the form of prevailing legacies of national oversight, as well as continued central state dominance in staffing, planning and even the distribution of funds.

Staffing costs make up a sizable portion of municipal expenditure and may thereby even threaten the ability of councils to decide freely on how to spend their funds. Reports on "shadow employees", i.e. clients of council elites that are on the cities' payroll but do not actually work, have been circulating after the recent reforms (interviews Casablanca, Dec 2018). We witness the opposite situation at the regional level, where staffing is so low that it is unclear whether the regional governments have the capacity to implement their projects adequately (see Figure 6 for the distribution of expenditures). Also, staff quality is relatively poor and many positions are unattractive in comparison to the ones in central state institutions (Bergh 2020). Overall, subnational governments accounted for only $9.7 \%$ of public staff expenditure in Morocco in 2016 (OECD and UCLG 2019). 
Figure 6: Distribution of expenditures in subnational governments in Morocco, 2018

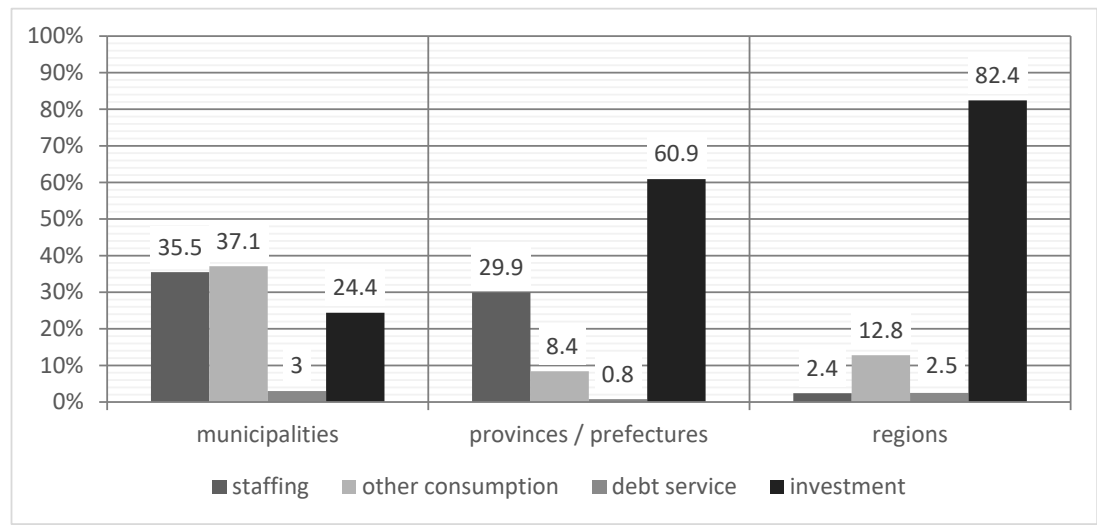

Own depiction based on data by TGR 2018.

The strong administrative oversight of subnational politics constrains the autonomy of subnational governments in Morocco (see also chapter 4). In addition, subnational councils are highly dependent on central state transfers. In 2016, 61.3\% of the Moroccan local budgets consisted of central state transfers (OECD and UCLG 2019), while the regional level received over $90 \%$ of its funding from transfers $(91.3 \%$ in 2018) (Vollmann et al. 2020). Though municipalities seem to be more independent, only the largest urban centers (especially Casablanca) generate significant portions of their budgets from their own income. Rural local councils receive around $70 \%$ of their budgets from the central state (Vollmann et al. 2020).

The overall institutional landscape limits the autonomy of democratically backed subnational council action and upholds the neopatrimonial power concentration of the regime: The budget plans still need the ex-post approval by representatives of the Ministry of Interior. Moreover, subnational council politics compete with central state sectoral initiatives that also target subnational politics. Palace-led development initiatives (e.g. National Initative for Human Development (INDH) or the National Program on Social and Territorial Disparities) are often more visible. Subnational governments are even part of the INDH and contribute funds to the program, although it is nonetheless dominated by the Ministry of Interior. Another example are development initiatives under the auspices of the wali who act as agents of the MoI in the regions (Agences de Développement Régional). There furthermore exists a myriad of de jure market ori- 
ented public national and regional agencies and state-owned companies that obscure the division of responsibilities between political actors, or encourage subnational governments to cooperate with the center (Vollmann et al. 2020; Bergh 2021; 2012; Houdret and Harnisch 2018).

\section{Fiscal decentralization in Jordan}

\section{Development of subnational finances: A sensitive balancing game}

Jordan initially established its municipal system in 1921 and incorporated it into the new constitution after the country's independence in 1946. It was not until 2015, however, that the kingdom initiated a decentralization process based on the Law on Decentralization (Law no. 49 of 2015). Jordan's system of subnational governance is organized along two administrative tiers: the governorate level comprising 12 governorates, and the municipal level consisting of 103 municipalities. The governorate level mainly functions as the extended arm of the Ministry of Interior (MoI) in the periphery and has a focus on security matters. The municipal councils and mayors are elected institutions carrying some minor responsibilities that affect their communities' everyday life, such as waste management and urban planning. Before the decentralization reform was finally implemented in 2017 (two years after the passing of the law), municipalities were the sole elected subnational institutions with the authority to create their own revenues and to spend their budget autonomously, however within limits, as budget generation and expenditure are under strong ministerial oversight.

The divide between Transjordanians and Palestinians is essential to the analysis of subnational dynamics in Jordan. The Transjordanian elite is considered the backbone of the Hashemite monarchy and traditionally dominates most of the public state institutions that constitute Jordan's main employer. Jordan's Palestinian population entered the country as refugees after 1948 and makes up the majority of Jordan's population today. They are mainly engaged with the private sector and are less integrated into state institutions compared to Transjordanians. The majority of Jordan's 10.5 million population (Department of Statistics Jordan 2019) lives in the three urban centers Amman, Zarqa, and Irbid, which are also the three governorates with the highest percentage of Palestinians. Over the years, the bulk of public state expenditures either went to Amman the capital city, economic center of the country, and home to around $40 \%$ of the population (OECD and UCLG 2019) - or to majority-Transjordani- 
an governorates of great socio-political influence, such as Karak or Ma'an, in order to appease the Transjordanian elite. Heterogenous governorates with a high percentage of Palestinians or a strong oppositional background, such as Zarqa and Irbid, received disproportionally fewer financial resources over time.

In 2008, Jordan spent 3.5\% of its GDP on subnational governance, $2.1 \%$ in 2013 , and $2.3 \%$ in 2016 . This amounts to $9.6 \%$ of the general government expenditures in 2008, 5.8\% in 2013, and 8\% in 2016 (UCLG 2010; OECD and UCLG 2019; 2016a). In comparison, Jordan's military expenditures made up 4.6\% of the GDP in 2016, one of the highest shares worldwide (World Bank 2020). Jordan's expenditures tend to fluctuate considerably each year, nevertheless the numbers illustrate a slight decrease in subnational governance spending over time.

\section{Regional disparities: A tiny country, yet highly unequal financial flows}

Although the Jordanian regime is hesitant to publish numbers on municipal revenues and expenditures, the Ministry of Local Administration (MoLA) made available its data for the years 2017 to 2019 during our fieldwork. The documents do not include the financial resources of the economic heavyweights Greater Amman Municipality, Aqaba Special Economic Zone and Petra Regional Authority, as they fall directly under the jurisdiction of the Prime Ministry. Thus, the governorates Amman, Aqaba and Ma'an had to be excluded from this part of the analysis since no further data is available. Nevertheless, the evaluation of per capita municipal expenditures and revenues of 2018 and 2019 illustrate major differences between the financial resources of the remaining nine governorates (see Figure 7). 
Figure 7: Municipal finances in Jordan's governorates per capita in USD
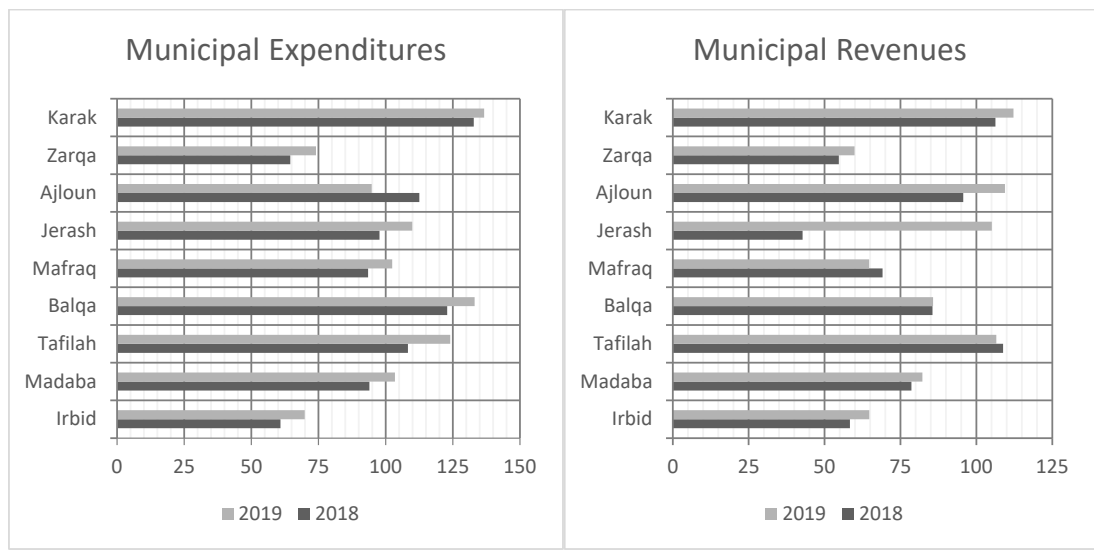

Own calculation based on data of the MoLA and the Department of Statistics Jordan.

Municipalities within the heterogenous, urban governorates Zarqa and Irbid, who have high percentages of Palestinians among their population, have significantly lower per capita expenditures than the other governorates. The same pattern applies for revenues, which include self-generated financial resources based on local fees, building permits and the tax on property, but also the central state transfers that most municipalities are dependent on $50 \%$ of the tax on oil derivates and $40 \%$ of vehicle license fees according to the Law on Municipalities 2015, as well as money borrowed from the Cities and Villages Development Bank). To exemplify, municipalities' own revenues in 2016 only accounted for 32\% of their budget (OECD and UCLG 2019, 522). Especially the municipalities in Karak, a governorate accommodating major parts of the Transjordanian political elite, show high numbers in both cases. This supports the claim that the distribution of decentralized funds favors the strongholds of the regime elite and their clients. It thus contributes to upholding neopatrimonial networks.

Overall, the per capita financial resources of majority-Transjordanian municipalities appear to be larger than those of the two majority-Palestinian urban governorates Irbid and Zarqa. Table 2 and 3 present data for the Greater Amman Municipality (GAM) from 2013 to 2016, which accommodated around $20 \%$ of the national population in 2016 . The revenues as well as the expenditures of GAM are higher in numbers than those of all other municipalities combined (OECD and UCLG 2019). But when comparing 
the per capita revenues and expenditures of GAM to those of the other municipalities in 2018/2019 (see Figure 7), municipalities in majority-Transjordanian governorates either equal or surpass the per capita resources of GAM.

Table 2: GAM expenditures

\begin{tabular}{|c|c|c|c|}
\hline & Population & Expenditures (in million USD) & Per capita (in USD) \\
\hline 2014 & $3,598,600$ & 406.5 & 112.97 \\
\hline 2015 & $3,907,200$ & 444.1 & 113.67 \\
\hline 2016 & $4,004,800$ & 447.8 & 111.82 \\
\hline
\end{tabular}

Own calculation based on PEFA (2017) and Department of Statistics Jordan for population size.

Table 3: GAM revenues

\begin{tabular}{|c|c|c|c|}
\hline & Population & Revenues (in million USD) & Per capita (in USD) \\
\hline 2013 & $3,316,800$ & 361.4 & 108.96 \\
\hline 2014 & $3,907,200$ & 407.9 & 104.41 \\
\hline 2015 & $4,004,800$ & 444.4 & 110.97 \\
\hline
\end{tabular}

Own calculation based on PEFA (2017) and Department of Statistics Jordan for population size.

Other than the municipalities, the governorate institutions manage all central state affairs within their territory, including security and police, and are thus closely supervised by the Ministry of Interior (MoI). Likewise, the respective central ministries and their directorates within each governorate control all fiscal matters of the governorate - including infrastructure and development projects as well as security related issues. The governorate institutions cannot collect own revenues and their ability to spend money autonomously is strictly limited. Thus, the task of compiling financial resources and expenditures of Jordan's governorate institutions resembles a hurdle race. Official documents list all ministerial expenditures including those on governorate affairs, but it is impossible to determine the exact amounts that accurately add up to the governorate budget.

When the Jordanian parliament passed the law on decentralization in 2015, domestic non-governmental organizations (NGOs) and international organizations had high hopes that the reform would increase fiscal decentralization. While the reform barely touched municipal affairs, it established a governorate council within each governorate - a partly elected institution (15\% of the members are appointed) with an annual budget to 
spend on infrastructure and development projects. Before the reform, investments in the governorates were decided by the central ministries, e.g. the Ministry of Health or Ministry of Agriculture. This procedure used to be rather arbitrary, as most investment decisions were based on the personalist patron-client relations of the ministerial staff. An official document of 2013 lists central infrastructure projects in the governorates, illustrating the unequal regional distribution of central investments (see Table 4). Although the list does not include Amman and Aqaba, it shows that rural, majority-Transjordanian governorates such as Ma'an and Tafilah received up to ten times higher rates of investments per capita than the heterogenous governorates Irbid and Zarqa.

Table 4: Distribution of central state investments across governorates in Jordan 2013

\begin{tabular}{|c|c|c|c|}
\hline & Population & $\begin{array}{c}\text { Central state invest- } \\
\text { ments (in million USD) }\end{array}$ & Per capita (in USD) \\
\hline Irbid & $1,506,900$ & 6.4 & 4.27 \\
\hline Mafraq & 468,200 & 6.6 & 14.14 \\
\hline Jerash & 201,800 & 6.4 & 31.95 \\
\hline Ajloun & 149,900 & 6.6 & 43.76 \\
\hline Amman & $3,411,200$ & n.a. & n.a. \\
\hline Balqa' & 418,600 & 6.2 & 14.91 \\
\hline Zarqa & $1,161,900$ & 6.8 & 5.82 \\
\hline Ma'daba & 161,100 & 6.4 & 39.45 \\
\hline Karak & 269,500 & 6.3 & 52.23 \\
\hline Ma'an & 122,700 & 6.4 & 78.27 \\
\hline Tafilah & 82,000 & 6.4 & n.a. \\
\hline Aqaba & 160,200 & n.a. & \\
\hline
\end{tabular}

Own calculation based on data of the General Budget Department and the Department of Statistics Jordan for population size.

Hence, one of the official reasons for Jordan's decentralization reform of 2015 was to equalize the distribution of central state investments between the governorates. The decentralization law ensures an annual budget calculation for development projects based on the socio-economic details of each governorate (for details see Vollmann et al. 2020). Table 5 lists each governorate council's budget from the first fiscal year of 2018 until 2020. 
Table 5: Governorate council budgets in Jordan, in USD

\begin{tabular}{|c|c|c|c|c|c|c|c|}
\hline \multirow{2}{*}{} & \multicolumn{3}{|c|}{$\mathbf{2 0 1 8}$} & \multicolumn{2}{|c|}{2019} & \multicolumn{2}{c|}{2020} \\
\cline { 2 - 8 } & Population & $\begin{array}{c}\text { Budget } \\
\text { (millions) }\end{array}$ & $\begin{array}{c}\text { Per capi- } \\
\text { ta }\end{array}$ & $\begin{array}{c}\text { Budget } \\
\text { millions) }\end{array}$ & $\begin{array}{c}\text { Per capi- } \\
\text { ta }\end{array}$ & $\begin{array}{c}\text { Budget } \\
\text { (millions) }\end{array}$ & $\begin{array}{c}\text { Per capi- } \\
\text { ta }\end{array}$ \\
\hline Irbid & $1,911,600$ & 32.4 & 16.93 & 42.3 & 22.10 & 34.0 & 17.80 \\
\hline Mafraq & 593,900 & 26.7 & 44.95 & 35.9 & 60.47 & 28.8 & 48.51 \\
\hline Jerash & 256,000 & 21.1 & 82.38 & 28.2 & 110.04 & 23.2 & 90.54 \\
\hline Ajloun & 190,200 & 22.3 & 117.13 & 29.6 & 155.51 & 24.2 & 126.99 \\
\hline Amman & $4,327,800$ & 48.5 & 11.22 & 64.8 & 14.97 & 53.2 & 12.30 \\
\hline Balqa' & 531,000 & 23.1 & 43.50 & 31.7 & 59.68 & 25.3 & 47.56 \\
\hline Zarqa & $1,474,000$ & 28.6 & 19.42 & 38.7 & 26.28 & 31.8 & 21.54 \\
\hline Ma'daba & 204,300 & 19.3 & 94.39 & 28.2 & 137.88 & 22.3 & 109.08 \\
\hline Karak & 341,900 & 20.2 & 59.16 & 30.9 & 90.63 & 21.3 & 62.23 \\
\hline Ma'an & 171,100 & 26.9 & 157.40 & 36.6 & 214.03 & 28.7 & 167.91 \\
\hline Tafilah & 104,000 & 19.4 & 186.69 & 28.9 & 277.63 & 22.3 & 214.61 \\
\hline Aqaba & 203,200 & 21.3 & 104.88 & 26.8 & 131.70 & 22.9 & 113.18 \\
\hline Total & $10,309,000$ & 30.9 & & 42.3 & & 33.8 & \\
\hline
\end{tabular}

Own calculation based on data derived of the General Budget Department 2018; 2019; 2020; Department of Statistics Jordan for population size.

Table 5 illustrates that Amman, Zarqa, and Irbid receive significantly fewer financial resources per capita than the rest of the governorates. Thus, despite the positive expectations connected with the decentralization law, the financial gap between urban heterogenous governorates and rural Transjordanian governorates remains. Additionally, one major change immediately stands out when comparing the numbers to those of 2013: The amount of central investments to the governorates has increased significantly. Central institutions, including ministries, are still running other large-scale projects, but the governorate councils are newly included in the decision-making processes on large financial sums. While this appears to be a decisive step towards sustainable economic and infrastructural development of the governorates, the de facto situation is different. The data of Table 5 are based on estimated budget numbers instead of the actual final count. Although the official final account for 2018 suggests that the governorate councils' budget was spent entirely (General Budget Department 2018), interviews with governorate council members across Jordan as well as domestic organizations indicate otherwise: According to various sources, only small percentages of the budget actually went into the implementation of the projects. For instance, the Zarqa governorate council was assigned 28.6 million USD (20.3 million JOD) for 2018, but only a total of 
around 2 million JOD were spent on the projects it has decided on during the entire year (Karak Castle Center for Consultation and Training 2018). A combination of formal and informal factors may explain this gap. Firstly, subnational council funds that have not been spent until the end of the fiscal year are not transferable to the next year's budget. Secondly, a highly inefficient procurement process makes it almost impossible to finish large projects within the same fiscal year. Hence, the rest of the implementation must be financed by the budget of the following year (for details see Karmel and Bohn 2020). Thirdly, a lack of commitment on behalf of the ministries as well as corruption frequently delay or halt the implementation. It is a common practice that ministries suddenly stop the implementation of projects or no longer transfer payments to the contractors. Lastly, the allocated budget for governorate projects is so high that most organizations on the ground simply assume that central institutions cannot afford to spend that much money on subnational development. Our interviews indicate major regional differences regarding the de facto implementation of projects, but since the regime does not provide the necessary data, there is no further proof to support these claims.

\section{Subnational finance and the central state: High levels of central control and clientelism}

The enormous influence of the central state on subnational fiscal affairs is present on all levels. The majority of municipalities is chronically indebted and highly dependent on central transfers. One of the main reasons for Jordanian municipalities' debt is overstaffing. Several reform initiatives since the early 2000s have helped to re-organize and reduce the bloated municipal institutions, but the situation remains problematic. In 2016, 22.6\% of Jordan's subnational budget went into staff expenditures, which clearly exceeds the OECD average (OECD and UCLG 2019, 521). Inter alia, Zarqa municipality officially had 4,359 employees in 2019 (MoLA 2019), which is by far the highest number of employees amongst Jordan's municipalities after GAM, the Aqaba Special Economic Zone, and the Petra Regional Authority ${ }^{4}$. One of the city's former mayors was a member of Bani Hasan, the dominant Transjordanian tribe in Zarqa. He used his position to employ thousands of Bani Hasan members who have remained on the payroll of

4 GAM, for instance, occupied more than 22.000 employees in 2015/2016 (PEFA 2017). 
the municipality until today, most of them as shadow employees who are salaried without actually working. In an interview, a representative of the MoLA classified this as an unsolvable situation. It would require the ministry to fire at least three-quarters of the employees, which, in turn, would prompt the majority of Bani Hasan to gather in protests in Amman until the ministry reverses the decision. Thus, Zarqa municipality has enormous staff costs each year (e.g. 89\% of the total revenues in 2019). According to interviews, by February 2020 Zarqa municipality had already spent its entire budget for the year on staff costs. This is a convenient example for the impact of patron-client networks on fiscal decentralization. Municipalities may apply for loans at the Cities and Villages Development Bank (CVDB), which is the institution that manages the municipalities' budget since 2010. The distribution of loans by the CVDB, however, is dependent on the mayor's personal relationship with the Minister of Local Administration, who is a member of the CVBD's board. Again, neopatrimonial networks are decisive: Controversial mayors are frequently denied loans and are consequentially unable to provide financial support for their territory.

On the governorate level, even after the decentralization reform fiscal matters remain under the control of central ministries. To the disappointment of domestic and international organizations - and not least to the council members themselves - the elected governorate councils do not have any authority over the spending of their budget. Their role is limited to the discussion of the development presented to them by the appointed executive council within the governorate that consists of ministerial staff. Even the implementation of the projects is the sole responsibility of the central ministries and their directorates within the governorate.

\section{Fiscal decentralization in Tunisia}

\section{Development of subnational finances: Governance turnaround underway? Spending increases without clear vision}

Tunisia's decentralization project is the only reform in our case selection that is taking place in a transition from authoritarianism to democracy. Since the Tunisian independence in 1956, the country's political regimes have tried to establish a strong central state with a predominantly national identity. Decentralization reforms and subnational governance were means to enforce central party rule and state security. After ousting Ben Ali in the 2010 and 2011 uprisings that originated in Tunisia's periphery in Sidi Bouzid, the "new" Tunisia opted for radical change. The constitution 
of 2014 emphasizes decentralization and dedicates a whole chapter to the subject. It was drafted under the influence of Tunisian regime outsiders and is a clear dissociation from the old system. To spurn the infamous Ministry of Interior, the symbol of repression both in the capital and through its oversight of the subnational levels, decentralization was made the responsibility of a new ministry, the Ministry of Local Affairs and Environment. The administrative oversight in the bicephalic system (a legacy from French rule as in Morocco), however, remains the responsibility of the MoI. Reforms and a decentralization law were delayed until 2018, local governments in the transition period were appointed by the center. The future of the ambitious decentralization project in the young democracy remains unknown, as severe government crises bind resources and efforts on the national level, but all political actors remain verbally committed to the constitution and its emphasis on subnational governance. However, the center opted for a slow and long-term implementation (27 years) of the Local Collectivities Code of 2018.

Data on fiscal decentralization in Tunisia are relatively rare and ambiguous with significant differences in numbers between various sources. When comparing data published by the OECD and the organization United Cities and Local Governments (UCLG), we see a counterintuitive development of subnational spending in Tunisia: In 2008, Tunisia spent a meagre $1.9 \%$ of its GDP, but $9.6 \%$ of its general government expenditure on local government (UCLG 2010, 336). The uprisings jump-started a decentralization discourse, but Tunisia's local government spending slightly declined to $1.6 \%$ of its GDP before the new constitution codified decentralization. The spending focus had shifted even more to the central state, as only $4.3 \%$ of general government spending were local (OECD and UCLG 2016c). The latest available UCLG data suggest an increase in 2016 to 2.1\% of GDP and 7.8\% of government expenditure (OECD and UCLG 2019, 144). We witness the same trend in the local revenue development, with $2.5 \%$ of GDP or $8.2 \%$ of government revenue in $2008,2.1 \%$ or $6.5 \%$ respectively in 2012 and $2.1 \%$ or $6.4 \%$ in 2016 (OECD and UCLG 2019; 2016c; UCLG 2010). Municipal data from the Ministry of Finance, however, record a rising trend after 2018 that can be expected to increase in the future.

We have also included the officially reported data by the Ministry of Finance for 2019. However, they have been updated between our first extraction in the end of November 2019 and February 2020. While the first extraction showed similar dimensions as 2018 and is still the data presented at the Ministry of Local Affairs and Environment, the new values show an increase by the factor 3.2 between the MoLAE data of 2018 and the new 
data of the MoF (see Figure 8). This would indicate a surge of municipality expenditures from 1.7\% of GDP or 5.6\% of public expenditure in 2018 to $6 \%$ of GDP and $17.3 \%$ of government spending in 2019. But it is unclear how local councils should have been able to spend thrice their original annual budget within one month (December 2019). This reminds us of the importance of the issue of availability and quality of financial data in the MENA region. ${ }^{5}$

Figure 8: Tunisian subnational expenditures (in million USD)

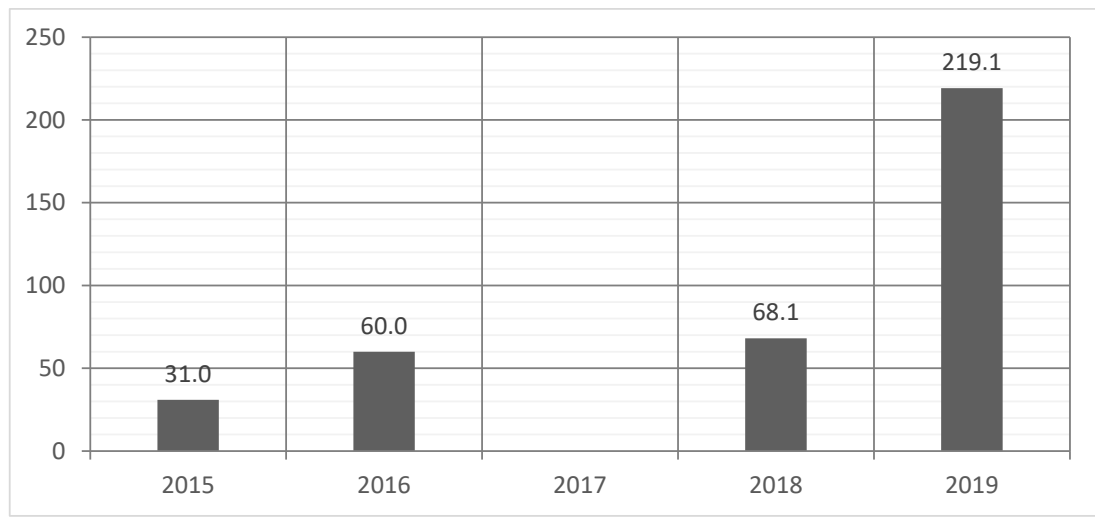

Own calculation based on data by the MoF and the MoLAE (for 2018), no data for 2017.

Regional disparities: Ongoing central dominance and peripheral neglect

The suicide of Mohamed Bouazizi in Sidi Bouzid sparked the so-called Arab Spring and reminds us of the political, economic and social disparities in Tunisia. Tunisian authoritarianism was closely connected to the dominance of the center and coastal Sahel elites over the interior regions. Their neopatrimonial networks concentrated political and economic power in the center. Decentralization is meant to be part of the remedy for this problem.

5 Data provided by UCLG reports slightly deviates from the data extracted from the Tunisian MoF. Data provided by the latter is generally slightly lower. One reason might be that reports of financial data for some municipalities was missing in the MoF data. 
Our data show that decentralization expenditure in Tunisia is still highest in Tunis. Since almost $20 \%$ of the Tunisian population lives in the capital and its surrounding governorates, a concentration of funding in the center can be expected. However, a comparison of the subnational per capita expenditures between the different regions demonstrate a preference for Grand Tunis and the coastal areas, where the Tunisian regime elite originates from. The cities of the governorate Tunis spent 102 USD per person in 2018. The spending of the surrounding and coastal governorates (e.g., Ariana, Ben Arous, Monastir, Sousse, Nabeul) is much higher than the national average of 61 USD per capita. Yet large parts of the traditionally neglected periphery spent even less, with Le Kef taking the last place (29.7 USD pc). Kairouan (32 USD pc) and Sidi Bouzid (35 USD pc) did not spend considerably more (see Table 6). The economic, ministerial and many other political elites' networks survived the fall of Ben Ali's regime and Tunisia's pacted transition. Despite the official credo of "positive discrimination" subnational spending seems to favor the traditional center and origins of Tunisia's old neopatrimonial elites. Fiscal decentralization has not overcome the center-periphery dynamics. Since subnational spending (as of now) still makes up only a very small portion of government expenditures, the dominance of the capital Tunis (ministries, national agencies and enterprises) and the Sahel (tourism) ${ }^{6}$ is bound to remain.

Table 6: Regional disparities of municipal spending in Tunisia 2018

\begin{tabular}{|c|c|c|c|}
\hline & $\begin{array}{c}\text { Population } \\
\text { (census 2014) }\end{array}$ & $\begin{array}{c}\text { Expenditure (in } \\
\text { million USD) }\end{array}$ & Per capita (in USD) \\
\hline Tunis & $1,056,247$ & 108.5 & 102.71 \\
\hline Ariana & 576,088 & 54.0 & 93.64 \\
\hline Ben Arous & 631,842 & 52.7 & 83.40 \\
\hline Monastir & 548,828 & 44.2 & 80.60 \\
\hline Sousse & 674,971 & 48.7 & 72.15 \\
\hline Nabeul & 787,920 & 56.3 & 71.48 \\
\hline Zaghouan & 176,945 & 11.8 & 66.89 \\
\hline Kasserine & 439,243 & 28.0 & 63.65 \\
\hline Tozeur & 107,912 & 6.7 & 62.21 \\
\hline Gafsa & 337,331 & 20.5 & 60.90 \\
\hline
\end{tabular}

6 Tourism is the wounded backbone of the Tunisian economy. After terrorist attacks brought down the business in 2015, the Corona pandemic of 2020 dealt another blow to this industry and the struggling Tunisian economy. The crisis will likely deepen the existing regional disparities (see also Dridi 2020). 


\begin{tabular}{|c|c|c|c|}
\hline & $\begin{array}{c}\text { Population } \\
\text { (census 2014) }\end{array}$ & $\begin{array}{c}\text { Expenditure (in } \\
\text { million USD) }\end{array}$ & Per capita (in USD) \\
\hline Sfax & 955,421 & 56.0 & 58.61 \\
\hline Siliana & 223,087 & 12.7 & 50.77 \\
\hline Tatouine & 149,453 & 7.6 & 47.34 \\
\hline Kebili & 156,961 & 7.4 & 47.20 \\
\hline Bizerte & 568,219 & 26.8 & 42.83 \\
\hline Medenine & 479,520 & 20.5 & 41.67 \\
\hline Manouba & 379,518 & 15.8 & 40.77 \\
\hline Gabès & 374,300 & 15.3 & 38.88 \\
\hline Béja & 303,032 & 11.8 & 38.68 \\
\hline Mehdia & 410,812 & 15.9 & 36.37 \\
\hline Jendouba & 401,477 & 14.6 & 34.82 \\
\hline Sizi Bouzid & 429,912 & 15.0 & 31.97 \\
\hline Kairouan & 570,559 & 18.2 & 29.65 \\
\hline Kef & 401,477 & 11.9 & 61.12 \\
\hline Overall & $11,141,075$ & 681.0 & \\
\hline
\end{tabular}

Own calculation based on MoLAE and Institute National de la Statistique.

Subnational finance and the central state: Underequipped local governments, infighting ministries, cautious governors

The allocation of subnational budgets is only the first step of implementing decentralization. As in Jordan and Morocco, Tunisian municipalities lack the capacity to autonomously spend local funds. Although data are scarce, our findings indicate that local council spending on investments and development does often not make use of existing funds. While the city of Tunis did manage to spend $93.26 \%$ of its planned budget for consumption (council administration, salaries, etc.), only $26.3 \%$ of the planned investments were spent by the end of the year 2015. The same is true for most municipalities in Tunisia. Sidi Bouzid, for example, spent around $85 \%$ of the funds that were planned for consumption, but only $33 \%$ of its investment plans (own compilation of 2015 data in MoF 2020).

The capacity to raise local taxes is extremely low - as is true for other parts of the MENA (Tarchouna 2019). The Tunisian population is reluctant to pay local fees and taxes because they argue that local governance should first improve the life of citizens. Since this is only possible by overcoming budget deficits, a vicious circle of local fiscal deprivation exists. The central government has long shown little interest in improving the 
municipalities' situation, and the MoLAE has opted for an amnesty of local fees of 2016 and prior years in 2019 (Marzouk 2019). Local tax recovery rates lie between 7\% and 20\% (Kherigi 2020b, 64).

Prior to the reforms, local authorities had no autonomous fiscal powers. But even in the new era, they are not given the chance to exercise real autonomy. The restricted ability of subnational councils to raise money leads to their prolonged dependency on the central state. In 2016, 69\% of the Tunisian subnational governments' budgets were central grants (OECD and UCLG 2019; Vollmann 2020, 18). Municipalities have also inherited a shortage of human resources because of their inferior role in the ancien régime. The local administration accounted for less than $10 \%$ of public sector employees before the 2018 decentralization law was passed (Kherigi $2020 \mathrm{~b}, 55)$. Only $3.4 \%$ of the public expenditure on staff was spent for local governments in 2016 (OECD and UCLG 2019). The percentage of skilled personal is also excessively low, between $4 \%$ and $10 \%$ between different municipalities (Kherigi 2020b; Turki and Gana 2015). Jobs in the local administration are not as attractive as in their national counterparts and municipal governance suffers from widespread vacancies (Tarchouna 2019). The situation is especially grave in the newly created municipalities, where equipment, staffing and even the provision of the council headquarters have to be built up without preexisting infrastructure.

Since the newly elected Tunisian mayors are largely unfamiliar with local administration and the new legal documents, they depend on their head of administration for a successful management of the territory. The secretary generals often have long experience in the public administration, which enables them to influence the politics of the elected councils. Mayors with experience in (local) administration seem to fare considerably better when dealing with their staff (see chapter 4).

The current legal framework's application has also discouraged local councilors' engagement with local politics. Since the mayor is the only local councilor who receives a salary (and he or she is not allowed to work in a different job simultaneously), many local councilors lack the resources to fully commit to their mandates or even participate in council meetings if they have no means of transport. This contributes to the high number of resigning mayors and the wave of mass defections from local councils in 2019 (see chapter 4). Elected councilors are thus badly equipped to act independently from the influence of appointed governors. The governor's powers of oversight (tutelle) and their omnipresence in the implementation of local politics have been reduced by the Local Government Law of 2018. However, the governors are better connected and have the power to enforce local politics, which the councils do not possess (e.g., control over 
the municipal police and deconcentrated offices of central ministries) (Kherigi 2020a). They also are reluctant or at least cautious to relinquish their hold of their old powers and hand the reigns to mayors and their councils (see chapter 4).

Obstacles to meaningful fiscal and political decentralization do not end with the relationship between elected local governments and the central state. Problems also lie in the regional offices of ministries that tend to have significantly less prestige than the government bodies in the capital. They, too, are largely understaffed. In some interior regions, more than $60 \%$ of jobs in deconcentrated central state institutions are vacant. This contributes to very low implementation rates of subnational investment and development programs (Kherigi 2020a).

Moreover, Tunisian ministries tend not to have a culture of inter-ministerial cooperation. The lack of a coherent political vision and the infighting of coalition partners that are political enemies have not helped either. The creation of the MoLAE did remove the subject of decentralization from the centripetal political agenda of the MoI. The ministry is new, relatively small and thus at a disadvantage in the negotiations with other government branches who are necessary to implement decentralization reforms, such as the MoI and the Ministry of Finance (Kherigi 2020b). The latter consider the decentralization law as of little interest for their own policymaking and feel bound to different administrative or financial laws. This has brought the decentralization process to a halt.

\section{Fiscal decentralization in Egypt ${ }^{7}$}

Development of subnational finances: Inefficient public service provision and rising military presence

The Egyptian case stands out with its two major power transitions during the past ten years. Since the foundation of the republic in 1953, making use of decentralization in order to equalize socio-economic imbalances between Egypt's 27 governorates has existed as a reoccurring idea (Ibrahim 2004, 12-29). But even after a decentralization discourse flourished follow-

7 The Egyptian case is only based on desk research. Due to the political situation in Egypt and the deteriorating academic freedom, we decided not to conduct fieldwork. Instead, we relied on an evaluation of existing literature, official state channels, media reports and statements of country experts. 
ing the breakdown of Mubarak's rule in 2011, the regime's will to genuinely decentralize remained questionable (Demmelhuber and Sturm 2016). The basic principles of the country's current subnational governance system under as-Sisi's rule are captured in the constitution of 2014. It stipulates a decentralized state structure and determines that Egypt's subnational governance system subdivides into three tiers with "legal personality", namely governorates, cities, and villages (Art. 175). But the constitution remains vague about further details that organize local governance, while the announced by-law to regulate the procedures is overdue. Currently, the regime sets its focus on expanding the role of the military and its associated branches - politically as well as economically (see chapter 4). By 2014, the military's contribution to Egypt's economic performance had reached around $40 \%$, but due to a lack of transparency, no detailed data are available (Roll 2014). As observers argue in the case of Egypt's general budget, it is reasonable to assume that the government tries to artificially scale down the official military budget by offshoring military-related spending to other branches. As-Sisi officially claims that the military received only $2 \%$ of the state budget and rejects reports that the army's expenditure is higher (Mukhtar 2020), yet it is clear that there was a significant upward trend and that for 2019/20 the "nominal military budget was 161 per cent higher than in 2010/11" (Kuimova 2020,4).

Egypt, too, is a prime example for the absence of reliable data on fiscal decentralization in the MENA. Official data record subnational spending in the form of "subnational administration". It is unclear, which sectors and public functions are included in these comparatively high numbers. From 1990 to 2019, between 9\% and 17\% of Egypt's public expenditures went into local administration, reaching a peak in the fiscal year of 2014/2015 (see Figure 9). The calculation includes subnational expenditures, but also all ministerial costs and those of other involved entities on the central and the subnational levels, which explains the comparatively high amounts. More than three quarters of the allocated subnational budget are spent on salaries each year. Characteristically for neopatrimonial rule, Egyptian local officials have no role in the employment process, because all staffing decisions are exclusively taken by central entities in Cairo. A certain percentage of local budgets (6\% in 2011) is allocated for central state expenditures on the local level as determined by the central authorities for specific sectors. Only a minor amount (around one fifth of the budget in 2011) is left for expenditures of the local units (Boex 2011). Altogether, this has often rendered the impact of local expenditures on subnational service provision and development inefficient, as the allocation responds to the interests of central ministries rather than the needs of the 
citizens (Tobbala 2019, 17). Already prior to as-Sisi's rule, Egypt's public sector was characterized by its inefficiency and high degrees of formal and informal central control.

Figure 9: Development of Egyptian state expenditures and share of subnational state expenditures 1990-2019, in billion USD

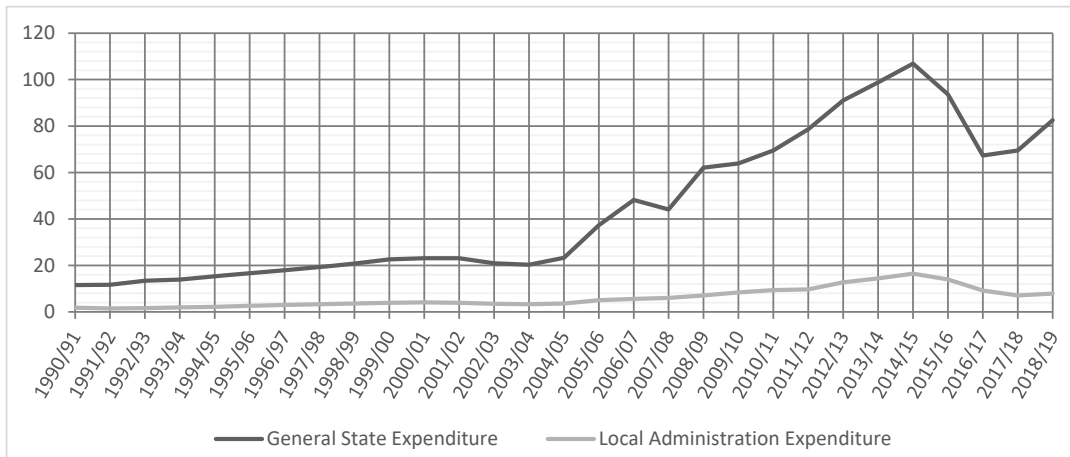

Own calculation based on data from the Ministry of Finance Egypt.

Regional disparities: Economic hubs, mega projects and the rest of the country

Official documents further break down the financial balance sheets into the shares of each of Egypt's 27 governorates. In order to illustrate regional imbalances, we calculated the per capita expenditures for each governorate for the fiscal year of 2017/2018 (see Table 7). Overall, subnational expenditures amounted to 7 billion USD in 2017/2018 for a population of 94.8 million, which accounts for $10.2 \%$ of Egypt's total state expenditures for that year. This percentage is higher than the shares of the other case studies, but has probably been artifically inflated. This is likely due to the fact that Jordan, Morocco and Tunisia report financial data of subnational councils, whereas Egypt reports an obscure amalgamation of data under the label "local administration". 
Table 7: Expenditures per governorate in Egypt in 2017/2018

\begin{tabular}{|c|c|c|c|}
\hline Governorate & Population size 2017 & $\begin{array}{c}\text { Subnational } \\
\text { expenditures } \\
\text { 2017/2018 (in million } \\
\text { USD) }\end{array}$ & Per capita (in USD) \\
\hline Kalyobiya & $5,627,420$ & 328.7 & 58.42 \\
\hline Suez & 728,180 & 76.0 & 104.38 \\
\hline Cairo & $9,539,673$ & 485.4 & 50.88 \\
\hline Alexandria & $5,163,750$ & 328.5 & 63.62 \\
\hline Sharqeia & $7,163,824$ & 560.7 & 78.27 \\
\hline Damietta & $1,496,765$ & 165.1 & 110.33 \\
\hline Kafr El Shiekh & $3,362,185$ & 274.5 & 81.63 \\
\hline The Red Sea & 359,888 & 72.8 & 202.40 \\
\hline El-Beheira & $6,171,613$ & 433.8 & 70.30 \\
\hline Assiut & $4,383,289$ & 320.6 & 73.15 \\
\hline Ismailia & $1,303,993$ & 139.5 & 106.98 \\
\hline New Valley & 241,247 & 94.7 & 392.68 \\
\hline Qena & $3,164,281$ & 266.4 & 84.18 \\
\hline South Sinai & 102,018 & 50.0 & 490.20 \\
\hline Sohag & $4,967,409$ & 341.7 & 68.79 \\
\hline Fayoum & $3,596,954$ & 207.5 & 57.70 \\
\hline Bani Souwaif & $3,154,100$ & 214.1 & 67.87 \\
\hline Port-Said & 749,371 & 113.8 & 151.92 \\
\hline Matrouh & 425,624 & 106.5 & 250.23 \\
\hline Menia & $5,497,095$ & 357.9 & 65.11 \\
\hline Dakahliya & $6,492,381$ & 555.0 & 85.48 \\
\hline Aswan & $1,473,975$ & 187.8 & 127.42 \\
\hline North Sinai & 450,328 & 138.4 & 307.32 \\
\hline Monofiya & $4,301,601$ & 371.8 & 86.44 \\
\hline Giza & $8,632,021$ & 320.9 & 37.18 \\
\hline Luxor & $1,250,209$ & 125.5 & 100.41 \\
\hline Al Gharbya & $4,999,633$ & 460.0 & 92.00 \\
\hline
\end{tabular}

Own calculation based on Census data 2017, data of the Ministy of Finance Egypt and UNFPA (2018).

South Sinai, New Valley, North Sinai, Matrouh, and Red Sea record the highest per capita expenditures. All five governorates are of strategic importance to the Egyptian regime, either politically or economically. While all five governorates experienced an increase in expenditures after 2010/2011, the expenditure growth for North and South Sinai can partly 
be interpreted as response to increasing unrest, criminal activities, and terrorist attacks of jihadists and occasionally associated Bedouins that have been marginalized by Egyptian regimes for decades. This challenge is especially problematic because of the Sinai Peninsula's strategic importance for Egypt. It is the eastern gateway into the country, rich in natural resources, and a relevant destination for tourism. New Valley and Matrouh are both close to the Libyan border and of strategic and economic importance as part of the country's strategy to secure economic development via largescale national projects (Roll 2014). For instance, the government is building a power plant in Matrouh - backed by a 25 billion USD loan from Russia - that is expected to deliver about $20 \%$ of the country's annual electrical power production when finished. In the same governorate, the regime opened a huge military base in 2017 , which is meant to respond to strategic threats from state collapse in Libya (Mohamed Naguib Military Base) (The Arab Weekly 2017). New Valley is strategically important for the development of Upper Egypt with the New Valley Project (Toshka Project) at the forefront. It is supposed to foster agricultural and industrial production - a project that has been in the making for a long time (initiated by Mubarak in 1997), but has only recently been revived by as-Sisi (Demmelhuber and Roll 2009; Mada Masr 2016). Finally, the Red Sea is one of the world's most frequented shipping routes, as it links the Suez Canal with the Gulf of Aden and thus is one of Egypt's most important economic hubs.

Verme et al. suggest that the financial gaps between urban and rural areas in Egypt are less visible than the discrepancies which appear when we compare Egypt's four main cities - Cairo, Alexandria, Port Said, and Suez - with the rest of the country (Verme et al. 2014). Using the latest available data of 2015, the World Bank classifies four regions in upper Egypt, namely Sohag, Assiut, Menia, and Qena, as those governorates with the largest shares of poor and vulnerable populations and the smallest shares of middle-class population. The same report classifies Cairo, Alexandria, Port Said, and Suez as those regions with the smallest shares of poor and vulnerable populations and the largest share of the middle-class populace (World Bank 2019). A comparison of the per capita expenditures of the eight governorates in 2017/2018 makes the fiscal gaps visible (see Figure 10). 
Figure 10: Per capita expenditures of Egypt's four governorates with the highest share of poor citizens (Quena, Menia, Assiut, Sohag) compared to the four main cities (Port-Said, Alexandria, Cairo, Suez) in 2017/2018, in USD

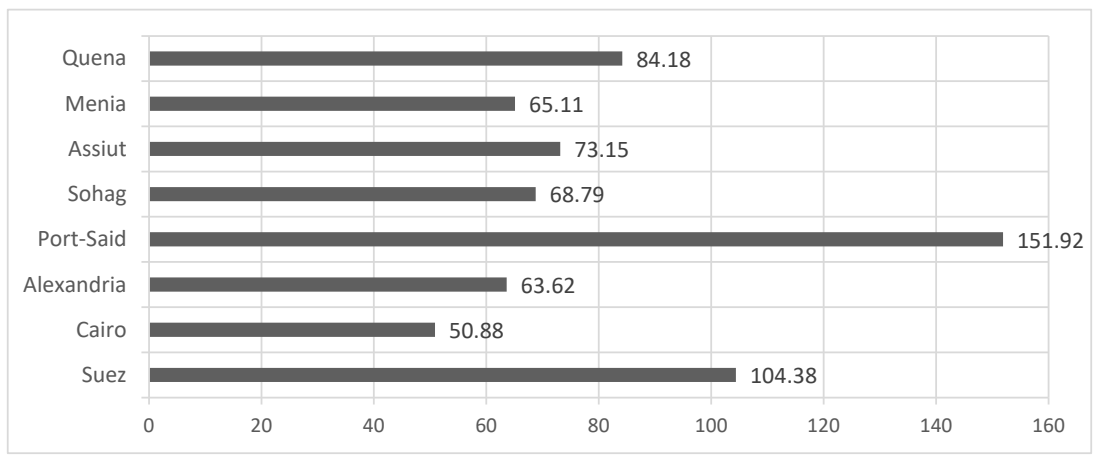

Own calculation based on data of the Ministry of Finance Egypt.

Suez and Port-Said fall out of line with exorbitantly higher expenditures than the poor governorates, but also compared to the spending of Cairo and Alexandria. Suez and Port-Said have always belonged to Egypt's historical, cultural, and economic hotspots. But with the inauguration of one of as-Sisi's megaprojects in 2015, which created a new canal that runs in parallel to the Suez Canal (the Suez Canal Corridor Area Project) to further develop the zone into an international trading and industrial hub, the cities of Suez, Port-Said, and Ismailia receive even more financial attention from the center (Al Arabiya English 2015).

A similar picture appears when we analyze the revenues of Egyptian governorates. Subnational institutions in Egypt are highly dependent on central transfers. Although they are allowed to generate their own revenues, the sums that are nominally generated on the local level are in truth largely loans from the center (International Budget Partnership and Budgetary and Human Rights Observatory 2015). Although the publicly available data on local revenues are scarce, we compiled the per capita revenues of each governorate between 2013 and 2019. Figure 11 depicts the accounts of the four main cities, Cairo, Alexandria, Port Said, and Suez, as well as those of Sohag, Assiut, Menia, and Qena (the four governorates with the largest shares of poor and vulnerable populations). The comparison suggests a picture similar to the analysis of subnational expenditures. Again, Suez and Port-Said are the front-runners in terms of revenue alloca- 
tion, especially during the time of the construction of the new canal between 2013/14 and 2015/16.

Figure 11: Per capita revenues of Egypt's four main cities (Suez, Cairo, Alexandria, Port-Said) compared to the four governorates with the highest share of poor citizens (Sohag, Assiut, Menia, Quena) between 2013-2019, in USD

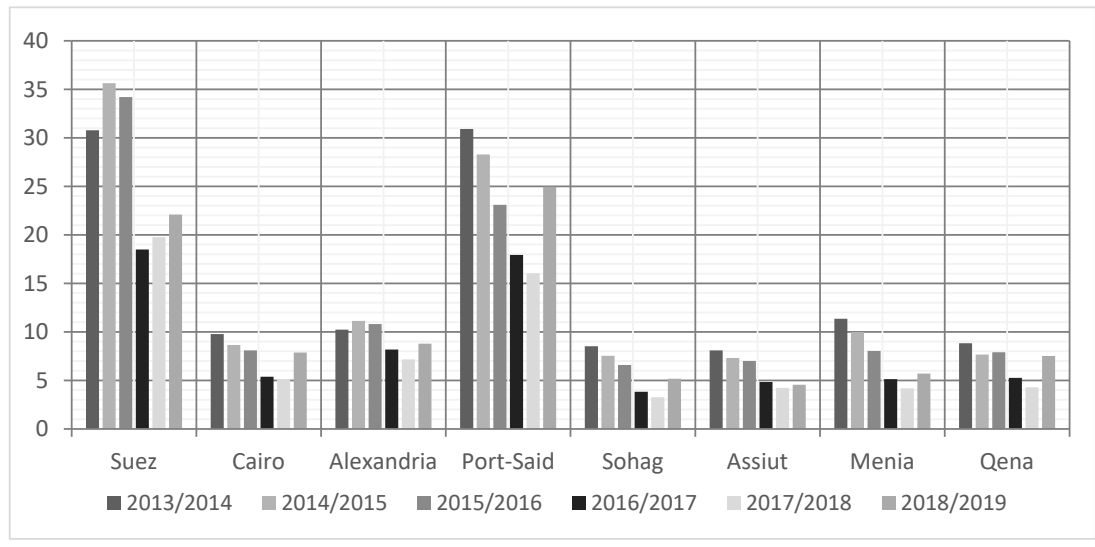

Own calculation based on data of the Ministry of Finance Egypt.

Subnational finance and the central state: High central control and hierarchy

As long as there is no new local administration law that further specifies fiscal relations, subnational financial affairs are guided by two main factors: (1) The strong presence of central control and (2) the hierarchy of local administrative units. Both factors reinforce the dominance of neopatrimonial networks. Over the past few decades, decisions on local budget generation and expenditures remained highly centralized with marginal inclusion of subnational actors. The constitution of 2014 specifies that each local unit has an independent financial budget whose "resources include, in addition to the resources allocated to them by the state, original and additional taxes and fees of a local nature" (Art. 178). Although the local units prepare their budget plans and requests, the line ministries de facto take the final decision. Traditionally, the process of budget allocation relies on negotiations between the Ministry of Finance and different public entities (Barsoum 2018). The hierarchy makes sure that each administrative unit is monitored by the respective upper level, which in turn pro- 
vides resources and instructions (Boex 2011). This also affects the fiscal affairs of local units: "The financial body is the governorate and it shall take charge of preparing the project of the governorate budget including projects of the local units' budgets within its scope (Art.120, law 43/1979)". Thus, all requests for expenditures at the lower administrative units must be collected and passed up to the governorate level, where they are added to an annual budget request for the whole governorate (Art. 120 - 124, law 43/1979). Eventually, the Ministry of Finance determines the local budget plans by taking into consideration the requests of the governorates as well as those of central ministries and other involved central entities (Boex 2011).

Way to go? - Long way to go: Careful progress in Morocco and Tunisia, stagnation in Jordan and Egypt

The era of fiscal decentralization has not yet arrived in the MENA region. While all four case studies use the language of decentralization and subnational finance, meaningful fiscal decentralization has yet to evolve from half-hearted legal changes and official rhetoric. Though comparable and reliable data are still rare, we can detect some trajectories in absolute spending when we compare the subnational fiscal situation of Egypt, Jordan, Morocco, and Tunisia before and after the Arab uprisings. All countries increased subnational state expenditures since the 1990s - not least due to IMF structural adjustment programs - but only Morocco and to some extent Tunisia record significant progress after 2011 (see Tables 8 and 9). Some of the higher expenditures can be ascribed to general government spending sprees in response to public protest, but the Moroccan and Tunisian reforms bear the potential to further increase fiscal decentralization in the future. Tunisia's path to decentralization is inconclusive as of now, but it suggests a radical break with the hyper-centralization during Ben Ali's regime. In Jordan and Egypt, however, the usual annual fluctuations of subnational expenditures remained in place even after 2011. Egypt's president as-Sisi is still in the process of consolidating his rule (see e.g. Noll 2019) and has blocked all meaningful implementation of decentralization, and above all the implementation of fiscal decentralization. AsSisi's focus is set on his mega projects as well as on improving the political and economic role of the military, rather than on local governance reforms. In Jordan, the decentralization law of 2015 had a disappointingly low impact on fiscal decentralization. The reform did not significantly increase subnational state expenditures, nor did the autonomy of local and 
regional councils allow them to manage their financial affairs. Far-reaching fiscal decentralization could have significant impact on pre-existing neopatrimonial networks and ties between the center and the local level. At the present, the Jordanian regime is not willing to risk such changes.

Table 8: Subnational spending as percentage of GDP

\begin{tabular}{|c|c|c|c|}
\hline & $\mathbf{2 0 0 7 / 2 0 0 8}$ & $\mathbf{2 0 1 3}$ & $\mathbf{2 0 1 6}$ \\
\hline Egypt & 4.6 & $3.3^{8}$ & $4.7^{9}$ \\
\hline Jordan & 3.5 & 2.1 & 2.3 \\
\hline Morocco & 2.2 & 3.7 & 3.4 \\
\hline Tunisia & 1.9 & 1.6 & 2.1 \\
\hline
\end{tabular}

OECD and UCLG (2016a; 2016c); UCLG (2010); OECD and UCLG (2019; 2016b).

Table 9: Subnational spending as percentage of General Government Spending

\begin{tabular}{|c|c|c|c|}
\hline & $\mathbf{2 0 0 7 / 2 0 0 8}$ & $\mathbf{2 0 1 3}$ & $\mathbf{2 0 1 6}$ \\
\hline Egypt & 10.9 & $13.4^{10}$ & $14.9^{11}$ \\
\hline Jordan & 9.6 & 5.8 & 8.0 \\
\hline Morocco & 7.6 & 11.8 & 11.8 \\
\hline Tunisia & 9.6 & 4.3 & 7.8 \\
\hline
\end{tabular}

OECD and UCLG (2016a; 2016c); UCLG (2010); OECD and UCLG (2019; 2016b).

Jordan, Tunisia and Morocco have all placed emphasis on the regional level as part of their de jure reforms, but only Morocco has sowed the seed for sustainable regionalization. This change is beginning to show in the financial endowments of the Moroccan regions, though the bulk of subnational spending, revenue generation, and staffing remains at the local level. If Morocco plans for the regions to be not only investment hubs for the central state but autonomous actors, Morocco needs to further accelerate its regional fiscal decentralization including human resources. Egypt is a more ambiguous case than the other three countries. Official data suggest comparatively high subnational state expenditures, without any trace of an implementation of its decentralization agenda after two power transitions since 2011. Fiscal decentralization data of most countries list the decentralized institutions' budgets, but Egypt only records an aggregated number

8 Data point for 2012/2013, own calculation based on MoF and IMF data.

9 Data point for 2015/2016, own calculation based on MoF and IMF data.

10 Data point for 2012/2013, own calculation based on MoF and IMF data.

11 Data point for 2015/2016, own calculation based on MoF and IMF data. 
for subnational administration. While deconcentration on its own would be a viable element of analysis, it is not clear if subnational administration only sums up deconcentrated services or if the numbers also include other state positions.

Regional disparities are central to the decentralization agendas of all four regimes. Our analysis suggests that decentralization is used in different ways to target the center-periphery nexus. Surprisingly, Tunisia still seems to uphold its general favoritism of the capital and the Sahel, the traditional origin of its political elites, when we compare per capita expenditures of local councils. While Morocco's central northern regions also seem to be the continuous winners of subnational council expenditures in absolute terms, the per capita analysis shows a more nuanced picture: Strategically important peripheral regions such as the Western Sahara or the conflict-prone Oriental Region spend more financial state resources per capita than the northern center. Political redistribution also occurs in Jordan: Zarqa, Irbid, and the capital Amman have the largest percentage of Palestinian communities amongst all Jordanian governorates. Our evaluation illustrates that majority-Transjordanian rural governorates, which are traditionally connected to the regime, receive larger amounts per capita than Zarqa and Irbid, the two largest and most urbanized governorates after Amman. As Jordan's economic powerhouse, Amman receives equal or even smaller amounts of per capita financial resources than majority-Transjordanian governorates. In this respect, it is noticeable that unlike the other municipalities, Greater Amman Municipality and Aqaba Special Economic Zone Authority are under direct supervision of the Prime Minister. Egypt's data, though very different in its content, suggests relatively little local administration spending on the capital Cairo, while poor governorates or regions of military interest, such as the Sinai Peninsula, are overrepresented with regard to per capita spending. Our per capita analysis also supports the above ranking of fiscal decentralization in the MENA: Morocco spent an average of 130.79 USD per inhabitant on decentralization (all subnational governments, 2019), Jordan follows with 92.92 USD per capita (2016 ${ }^{12}$, municipalities), and Egypt with 74.87 USD per capita (2017/18). Tunisia is at the rear end with 61.12 USD per capita in 2015, though the sum is likely to have increased since. Due to a lack of data and the limits of comparability of the Egyptian data, the years of reference vary in this comparison. We should thus be cautious with rash conclusions beyond illustrating a trend.

12 Calculation based on 2017 population data, thus likely slightly overrepresented. 
Our analysis also demonstrated that fiscal decentralization in the MENA suffers from high dependencies on central state transfers, weak subnational revenue generation, and problems with (local) tax collection. Combined with strong administrative oversight and general reservations of central actors and ministries towards subnational entities, the autonomy of subnational governments is low in all countries. Both overstaffing (Jordan, Egypt) and understaffing (Tunisia, Moroccan regions) occur in our cases and negatively affect the subnational governments' capacity to work and invest. Central actors and initiatives dominate the public sphere and most projects depend on the cooperation of subnational actors with the regime or central actors. The cases of Morocco, Tunisia and Jordan suggest that subnational governments fail to spend fully even the small amounts they are provided with.

Subnational governments thus often seem ill-equipped to contribute to the success of decentralization reforms in a significant way. An increase of human and financial resources as well as implementation capacities are crucial for successful subnational governance, but our four cases have so far failed to meet these requirements. Strong political will of the central regimes is necessary to move reform projects forward. Since the four countries are lower- to middle-income countries without full-fledged rent economies, increased financial commitment in any public sector is problematic. Public treasuries are often stretched thin and decentralization puts even greater strain on state funds. Further development of fiscal decentralization thus depends on far-reaching structural reforms and reallocations of resources from the top-heavy ministries down to subnational councils or deconcentrated ministerial branches. Without a doubt, this would sorely test established neopatrimonial networks and the political will of MENA regimes to decentralize.

\section{References}

Aalen, Lovise, and Rangnhild L. Murias. 2018. Manipulating Political Decentralization. Africa's Inclusive Autocrats. New York: Routledge.

Al Arabiya English. 2015. "What you Need to Know about the 'New Suez Canal'." Al Arabiya English, 31 July. Accessed January 29, 2021. https://english.alarabiya. net/perspective/analysis/2015/07/31/What-you-need-to-know-about-the-New-Sue z-Canal-.

Altunbaş, Yener, and John Thornton. 2012. "Fiscal Decentralization and Governance." Public Finance Review 40 (1): 66-85. doi: 10.1177/1091142111424276. 
Barsoum, Ghada. 2018. "Egypt's Many Public Administration Transitions: Reform Vision and Implementation Challenges." International Journal of Public Administration 41 (10): 772-780. doi: 10.1080/01900692.2017.1387145.

Bergh, Sylvia I. 2017. The Politics of Development in Morocco: Local Governance and Participation in North Africa. London: I.B. Tauris.

Bergh, Sylvia I. 2020. "Morocco's Decentralization Experience.” In The Dynamics of Decentralization in the MENA: Processes, Outcomes, and Obstacles, edited by Marwa Shalaby, Chagai Weiss, Ellen Lust, Kristen Kao, Erik Vollmann, Sylvia I. Bergh, Ezra Karmel, Miriam Bohn, Intissar Kherigi and Zeynep Kadirbeyoglu, 23-39. Gothenburg: GLD.

Bergh, Sylvia I. 2021. "Democratic decentralization and local development: insights from Morocco's advanced regionalization process." In Research Handbook on Democracy and Development, edited by Gordon Crawford and Abdul-Gafaru Abdulai, 482-501. Cheltenham: Edward Elgar.

Blöchliger, Hansjörg. 2013. "Measuring Decentralisation.” In Measuring Fiscal Decentralisation. Concepts and Policies, edited by Junghun Kim, Jorgen Lotz and Hansjörg Blöchliger, 15-35. Paris: OECD, Korea Institute of Public Finance.

Boex, Jamie. 2011. "Democratization in Egypt: The Potential Role of Decentralization.” Urban Institute Center on International Development and Governance. Accessed January 29, 2021. https://www.urban.org/sites/default/files/publication /27151/412301-Democratization-in-Egypt-The-Potential-Role-of-Decentralization .PDF.

Dardanelli, Paolo, John Kincaid, Alan Fenna, André Kaiser, André Lecours, and Ajay Kumar Singh. 2018. "Conceptualizing, Measuring, and Theorizing Dynamic De/Centralization in Federations.” Publius: The Journal of Federalism 49 (1): 129. doi: 10.1093/publius/pjy036.

Demmelhuber, Thomas, and Stephan Roll. 2009. "Zwischen Stabilisierung und Machterhalt: Ägyptens Regierungspolitik zum Abbau Regionaler und Sozialer Disparitäten." In "Sozio-regionale” Entwicklungsansätze in Nordafrika/Nahost: Ein Erfolgversprechender Weg zur Stabilisierung der Staaten?, edited by Sigrid Faath, 15-48. Hamburg: GIGA.

Demmelhuber, Thomas, and Roland Sturm. 2016. "Warum gibt es keinen Föderalismus in den Arabischen Ländern? Zur Dialektik von Autokratie und Dezentraler Herrschaft." In Jahrbuch des Föderalismus 2016, edited by Europäisches Zentrum für Föderalismus-Forschung Tübingen, 165-178. BadenBaden: Nomos.

Demmelhuber, Thomas, Roland Sturm, and Erik Vollmann. 2020. "Decentralization in the Arab World: Conceptualizing the Role of Neopatrimonial Networks.” Mediterranean Politics 25 (4): 499-521. doi: 10.1080/13629395.2018.1559 391.

Department of Statistics Jordan. "Population.” Accessed January 29, 2021. http://do sweb.dos.gov.jo/population/population-2/

Dridi, Manel. 2020. “Coronavirus and Tunisia's Regional Economic Inequalities." Carnegie Endowment, April 29. Accessed January 29, 2021. https://carnegieendo wment.org/sada/81686. 
General Budget Department. 2018. “Annual Report 2018.” Accessed January 29, 2021. http://www.gbd.gov.jo/Uploads/Files/issues/annual-report/ar/annual-repor t-2018.pdf.

General Budget Department Jordan. 2018. “Total of Capital Expenditures Distributed According to the Determined Ceilings for the Fiscal Year 2018." Accessed January 29, 2021. http://www.gbd.gov.jo/Uploads/Files/gbd/law-min/201 8/en/5.pdf.

General Budget Department Jordan. 2019. "General Budget Law for the Fiscal Year 2019.” Accessed January 29, 2021. http://www.gbd.gov.jo/ar/releases/law-min/20 19.

General Budget Department Jordan. 2020. "General Budget Law for the Fiscal Year 2020” Accessed January 29, 2021. http://www.gbd.gov.jo/ar/releases/law-min/202 0 .

Gervasoni, Carlos. 2010. "A Rentier Theory of Subnational Regimes: Fiscal Federalism, Democracy, and Authoritarianism in the Argentine Provinces." World Politics 62 (2): 302-340. doi: 10.1017/S0043887110000067.

Harb, Mona, and Sami Atallah. 2015a. "An Assessment of Decentralization and Service Delivery in the Arab World." In Local Governments and Public Goods: Assessing Decentralization in the Arab World, edited by Mona Harb and Sami Atallah, 229-234. Beirut: LCPS.

Harb, Mona, and Sami Atallah. 2015b. “A Framework for Assessing Decentralization in the Arab World." In Local Governments and Public Goods: Assessing Decentralization in the Arab World, edited by Mona Harb and Sami Atallah, 1-10. Beirut: LCPS.

Haut-Commissariat au Plan du Maroc. 2020. "Recensement Général de la Population et de l'Habitat de 2014.” Accessed January 29, 2021. https://www.hc p.ma/downloads/RGPH-2014_t17441.html.

Hibou, Béatrice. 2004. "Fiscal Trajectories in Morocco and Tunisia." In Networks of Privilege in the Middle East: The Politics of Economic Reform Revisited, edited by Steven Heydemann, 201-222. New York: Palgrave Macmillan US.

Houdret, Annabelle, and Astrid Harnisch. 2018. "Decentralisation in Morocco: a Solution to the 'Arab Spring'?" The Journal of North African Studies: 1-26. doi: 10.1080/13629387.2018.1457958.

Ibrahim, Solava. 2004. The Role of Local Councils in Empowerment and Poverty Reduction in Egypt. Cairo: AUC Press.

Institute National de la Statistique. 2014. "Recensement Général de la Population et de l'Habitat 2014 Principaux indicateurs.” Accessed January 29, 2021. http://w ww.ins.tn/fr/publication/recensement-g\%C3\%A9n\%C3\%A9ral-de-la-populationet-de-lhabitat-2014-principaux-indicateurs.

International Budget Partnership and Budgetary and Human Rights Observatory. 2015. "A Guide to the Egyptian Budget." Accessed January 29, 2021. https://ww w.internationalbudget.org/wp-content/uploads/A-Guide-to-the-Egypt-Budget.pd f. 
Karak Castle Center for Consultation and Training. 2018. "Legal Review of the Jordanian Decentralization Law: Final Report.” Friedrich Ebert Stiftung. Accessed January 29, 2021. http://library.fes.de/pdf-files/bueros/amman/15162.pdf.

Karmel, Ezra, and Miriam Bohn. 2020 "Decentralization in Jordan." In The Dynamics of Decentralization in the MENA: Processes, Outcomes, and Obstacles, edited by Marwa Shalaby, Chagai Weiss, Ellen M. Lust, Kristen Kao, Erik Vollmann, Sylvia I. Bergh, Ezra Karmel, Miriam Bohn, Intissar Kherigi, and Zeynep Kadirbeyoglu. Gothenburg: GLD.

Kherigi, Intissar. 2017. "Devolving Power After the Arab Spring: Decentralization as a Solution.” Al-Sharq. Accessed January 29, 2021. http://sharqforum.org/dow nload/4626/.

Kherigi, Intissar. 2020a. "Decentralisation: The Search for New Development Solutions in the Arab World's Peripheries.” Accessed January 29, 2021. https://www. arab-reform.net/publication/decentralisation-the-search-for-new-development-so lutions-in-the-arab-worlds-peripheries/.

Kherigi, Intissar. 2020b. "Tunisia's Decentralization Reforms: The Gap between Ideas and Implementation." In The Dynamics of Decentralization in the MENA: Processes, Outcomes, and Obstacles, edited by Chagai Weiss Marwa Shalaby, Ellen Lust, Kristen Kao, Erik Vollmann, Sylvia I. Bergh, Ezra Karmel, Miriam Bohn, Intissar Kherigi, Zeynep Kadirbeyoglu, 54-66. Gothenburg: GLD.

Kleider, Hanna, Leonce Röth, and Julian L. Garritzmann. 2017. "Ideological Alignment and the Distribution of Public Expenditures." West European Politics: 1-24. doi: 10.1080/01402382.2017.1395634.

Kuimova, Alexandra. 2020. "Understanding Egyptian Military Expenditure.” SIPRI Background Paper, October 2020. Stockholm: SIPRI.

Lust, Ellen, and Lise Rakner. 2018. "The Other Side of Taxation: Extraction and Social Institutions in the Developing World.” Annual Review of Political Science 21 (1): 15.1-15.18. doi: 10.1146/annurev-polisci-042716-102149.

Mada Masr. 2016. "Egypt Allocates Additional Land to Toshka Project." Mada Masr, August 12, Accessed January 29, 2021. https://www.madamasr.com/en/201 6/08/12/news/u/egypt-allocates-additional-land-to-toshka-project/.

Marzouk, Hamza. 2019. "L’Amnistie Fiscale Fournira aux Municipalités 80 Millions de Dinars.” L'Économiste maghrébin, February 4. Accessed January 29, 2021. https://www.leconomistemaghrebin.com/2019/02/04/lamnistie-fiscale/.

Mhammedi, Mehdi Alaoui. 2019. "Étude des Causes des Excédents Budgétaires dans les Structures Communales au Maroc.” ACCRA 4 (1): 11-32. doi: 10.3917/ accra.004.0011.

Ministère des Affaires Locales et de l'Environnement. 2020. "Portail des Collectivités Locales. Données Financières.” Accessed January 29, 2021. http://w ww.collectiviteslocales.gov.tn/fr/detail-de-donnees-financier/.

Ministère des Finances. 2020a. “Dépenses.” Accessed January 29, 2021. http://www. finances.gov.tn/fr/budget/depense.

Ministère des Finances. 2020b. "Ressources.” Accessed January 29, 2021. http://ww w.finances.gov.tn/fr/budget/recette. 
Ministry of Finance Egypt. 2020. “General Budget.” Accessed January 29, 2021. http://www.mof.gov.eg/English/Pages/FinalAccountsData.aspx.

Ministry of Local Administration Jordan (MoLA). 2019. "وضــع المجــالس البلديــة لعـام 2019," unpublished documents.

Ministry of Local Administration Jordan (MoLA). 2017. "20172, unpublished documents.

Mukhtar, Ibrahim. 2020. "Egypt Appoints Military Advisor for each Governorate.” Accessed January 29, 2021. https:/www.aa.com.tr/en/middle-east/egypt-appoints -military-advisor-for-each-governorate/1926413.

Noll, Jessica. 2019. "Fighting Corruption or Protecting the Regime? Egypt's Administrative Control Authority." Project on Middle East Democracy, February 6. Accessed January 29, 2021. https://pomed.org/.

OECD, and UCLG. 2016a. “Jordan.” Accessed January 29, 2021. http://www.uclg-lo calfinance.org/sites/default/files/JORDAN-MEWA-V3.pdf.

OECD, and UCLG. 2016b. “Morocco.” Accessed January 29, 2021. http://www.uclg -localfinance.org/sites/default/files/MOROCCO.pdf.

OECD, and UCLG. 2016c. "Tunisia.” Accessed January 29, 2021. http://www.uclg-1 ocalfinance.org/sites/default/files/TUNISIA-AFRICA-V3.pdf.

OECD, and UCLG. 2019. 2019 Report of the World Observatory on Subnational Government Finance and Investment - Country Profiles. Paris: OECD.

PEFA. 2017. "Public Expenditure and Financial Accountability Assessment: Greater Amman Municipality, The Hashemite Kingdom of Jordan. Public Expenditure and Financial Accountability Assessment, PEFA CHECK, Final Report.” Accessed January 29, 2021. https:/www.amman.jo/site_doc/pefa.pdf.

Roll, Stephan. 2014. "Al-Sisis Entwicklungsvisionen - Großbauprojekte und Herrschaftssicherung in Ägypten." Stiftung Wissenschaft und Politik (SWPAktuell 35). Accessed September 16, 2020. https://www.swp-berlin.org/fileadmi n/contents/products/aktuell/2014A35_rll.pdf.

Shalaby, Marwa, Chagai Weiss, Ellen Lust, Kristen Kao, Erik Vollmann, Sylvia I. Bergh, Ezra Karmel, Miriam Bohn, Intissar Kherigi, and Zeynep Kadirbeyoglu. 2020. The Dynamics of Decentralization in the MENA: Processes, Outcomes, and Obstacles., GLD Working Paper No. 31. Gothenburg: GLD.

Sigman, Rachel, and Staffan Lindberg. 2017. Neopatrimonialism and Democracy: An Empirical Investigation of Africa's Political Regimes, V-Dem Working Paper Series 2017: 56. Gothenburg: V-Dem Institute.

Tarchouna, Lotfi. 2019. "The Tunisian Experience of Decentralization Since 2014." Arab Reform Initiative, July 31. Accessed January 29, 2021. https://www.arab-ref orm.net/publication/the-tunisian-experience-of-decentralization-since-2014/.

The Arab Weekly. 2017. "Egypt Opens New Military Base with Many Objectives in Mind.” The Arab Weekly, August 6. Accessed January 29, 2021. https://thearabw eekly.com/egypt-opens-new-military-base-many-objectives-mind.

Tobbala, Salwa 2019. "Towards a Decentralized Governance System in Egypt." Journal of Public Policy and Administration 4 (1): 13-32. 
Trésorerie Générale du Royaume. 2009. Bulletin Mensuel de Statistiques des Finances Locales. Décembre 2009. Rabat: TGR.

Trésorerie Générale du Royaume. 2010. Bulletin Mensuel de Statistiques des Finances Locales. Décembre 2010. Rabat: TGR.

Trésorerie Générale du Royaume. 2011. Bulletin Mensuel de Statistiques des Finances Locales. Décembre 2011. Rabat: TGR.

Trésorerie Générale du Royaume. 2012. Bulletin Mensuel de Statistiques des Finances Locales. Décembre 2012. Rabat: TGR.

Trésorerie Générale du Royaume. 2013. Bulletin Mensuel de Statistiques des Finances Locales. Décembre 2013. Rabat: TGR.

Trésorerie Générale du Royaume. 2014. Bulletin Mensuel de Statistiques des Finances Locales. Décembre 2014. Rabat: TGR.

Trésorerie Générale du Royaume. 2015. Bulletin Mensuel de Statistiques des Finances Locales. Décembre 2015. Rabat: TGR.

Trésorerie Générale du Royaume. 2016. Bulletin Mensuel de Statistiques des Finances Locales. Décembre 2016. Rabat: TGR.

Trésorerie Générale du Royaume. 2017. Bulletin Mensuel de Statistiques des Finances Locales. Décembre 2017. Rabat: TGR.

Trésorerie Générale du Royaume. 2018. Bulletin Mensuel de Statistiques des Finances Locales. Décembre 2018. Rabat: TGR.

Trésorerie Générale du Royaume. 2019. Bulletin Mensuel de Statistiques des Finances Locales. Décembre 2019. Rabat: TGR.

Turki, Sami Yassine, and Alia Gana. 2015. "Les Territoires Ruraux en Tunisie à l'Épreuve de la Communalisation: Entre Complexité de la Réforme et Enjeux Politiques.” Maghreb - Machrek 226 (4): 53-71. doi: 10.3917/machr.226.0053.

UCLG. 2010. GOLD II: Local Government Finance: The Challenges of the 21st Century. Second Global Report on Decentralization and Local Democracy. Cheltenham: Edward Elgar.

UNFPA. 2018. "Egypt National Report: Addis Ababa Declaration on Population \& Development in Africa beyond 2014 (AADPD+5).” Accessed January 29, 2021. https://egypt.unfpa.org/sites/default/files/pub-pdf/Egypt\%20National\%20\%28A ADPD\%2B5\%29\%20Report\%20MidNov18\%20\%281\%29.pdf.

V-Dem Institute. 2021. “Global Standards, Local Knowledge.” Accessed January 29, 2021. https://www.v-dem.net/en/.

Verme, Paolo, Branko Milanovic, Sherine Al-Shawarby, Sahar El Tawila, May Gadallah, and Enas Ali A. El-Majeed. 2014. "Inside Inequality in the Arab Republic of Egypt: Facts and Perceptions across People, Time, and Space.” World Bank Study. Accessed January 29, 2021. https:/www.worldbank.org/content/da $\mathrm{m} /$ Worldbank/egypt-inequality-book.pdf.

Vollmann, Erik. 2020. "Comparative Decentralization in the MENA." In The Dynamics of Decentralization in the MENA: Processes, Outcomes, and Obstacles, edited by Marwa Shalaby, Chagai Weiss, Ellen Lust, Kristen Kao, Erik Vollmann, Sylvia I. Bergh, Ezra Karmel, Miriam Bohn, Intissar Kherigi and Zeynep Kadirbeyoglu, 9-22. Gothenburg: GLD. 
Vollmann, Erik, Miriam Bohn, Roland Sturm, and Thomas Demmelhuber. 2020. "Decentralisation as Authoritarian Upgrading? Evidence from Jordan and Morocco.” The Journal of North African Studies: 1-32. doi: 10.1080/13629387.2020.17 87837.

World Bank. 2001. "Intergovernmental Fiscal Relations.” Accessed January 29, 2021. http://www1.worldbank.org/publicsector/decentralization/fiscal.htm.

World Bank. 2019. "Understanding Poverty and Inequality in Egypt.” Accessed August 15, 2020. https://openknowledge.worldbank.org/bitstream/handle/10986/32 812/Understanding-Poverty-and-Inequality-in-Egypt.pdf.

World Bank. 2020. “World Bank Data.” Accessed January 29, 2021. https://data.wor ldbank.org. 